\title{
Controlling Shareholder Stock Pledge, Aggravated Expropriation and Corporate Acquisitions
}

\author{
Siyuan Yan, Xiaoxu Ling, and Louis T.W. Cheng*
}

*Yan, siyuan.yan@connect.polyu.hk, School of Accounting and Finance, The Hong Kong Polytechnic University; Ling, xiao-xu.ling@polyu.edu.hk, School of Accounting and Finance, The Hong Kong Polytechnic University; Cheng(corresponding author), louis.cheng@polyu.edu.hk. Mailing address: M715, Li Ka Shing Tower, The Hong Kong Polytechnic University, Hung Hom, Kowloon. Work phone number: (+852) 6765-3194.

We appreciate valuable comments and suggestions from session participants at the European Financial Management Association (EFMA) 2020 annual meeting; Asia-Pacific Conference on Economics \& Finance (APEF 2020); American Accounting Association (AAA) 2020 Mid-Atlantic Region Meeting; Spark - AAA's Virtual Meeting; and AAA 2020 Annual Meeting.

The datasets generated during and/or analysed during the current study are publicly available and available from the corresponding author on reasonable request. All errors and omissions are our own. 


\title{
Controlling shareholder Stock Pledge, Aggravated Expropriation and Corporate Acquisitions
}

\begin{abstract}
This study examines the effect of controlling shareholder stock pledge on corporate acquisition decisions and associated performance. Using the sample of listed firms in China, we find that pledging firms, consistent with the aggravated expropriation hypothesis, initiate more takeovers, and further, acquisitions conducted by pledging firms obtain lower announcement returns. We address the endogenous concerns by using the instrumental variable and the difference in differences approaches. Moreover, our channel tests suggest that pledging acquirers overpay in the deals and are more likely to be involved in related party transactions. Cross-sectionally, we find that the relationship between the share pledge and returns is stronger for non-SOEs and firms with high-level free cash flow. Lastly, we find that pledging acquires underperform in the long-run in terms of lower ROA and a greater likelihood of goodwill impairment. Overall, our findings indicate that controlling shareholders increasingly expropriate minority shareholders' interest through self-serving corporate takeovers after the stock pledge.
\end{abstract}

Keywords: Stock pledge; Controlling Shareholder; Expropriation; Merger and Acquisition; Agency Problem JEL Classifications: G34; G32; G14 


\section{Introduction}

Stock pledges by the corporate controlling shareholder in exchange for personal loans ${ }^{2}$ is an international phenomenon which can be observed in worldwide developed financial markets such as the U.S., the U.K, Australia, Honk Kong, and Singapore, as well as in emerging economies such as China, Taiwan, and India (e.g., Chen et al., 2018; Ouyang et al., 2019; Dou et al., 2019). Nevertheless, concerns and debates exist among the government, academic researchers, the media, and investors on the growing prevalence of the insider's stock pledge due to the mixed results exhibited in the extant literature. On the one hand, some studies show that the controlling shareholder stock pledge has negative impacts on corporate decisions and the shareholder's wealth (e.g., Chen et al., 2018; Dou et al., 2019). More specifically, they document that the stock pledge is associated with greater equity risk exposure and agency problems, subsequently triggering pricesupporting share repurchase activities (Chan et al., 2018), decreased executive pay-forperformance sensitivity (Ouyang et al., 2019), decreased cash dividend payouts (Li, Zhou. Yan, and Zhang, 2019); more earnings management (DeJong, Liao, and Xie, 2020; Signgh; 2018) and reduced innovation productivity (Pang and Wang, 2020). However, on the other hand, some research concludes that the stock pledge is not harmful to shareholder wealth and is even positively associated with firm value by arguing that the pledging can signal the corporate insider's confidence in a firm's future performance (e.g., Chen and Hu, 2018; Li, Liu, and Scott, 2019).

To shed light on this debate, we empirically examine, for the first time in the literature, how the controlling shareholder stock pledge would affect corporate merger and acquisition $(M \& A)^{3}$ decision and associated performance based on the sample of listed firms in China. There

${ }^{2}$ In our sample, the data shows that $95 \%$ of the stock pledge is for personal use; $1.88 \%$ is for the original company, and $3.06 \%$ is for the third party.

${ }^{3}$ In this paper, we use the merger and acquisition, M\&A, acquisition and takeovers interchangeably. 
is an increasing tendency for the stock pledge to be made by controlling shareholders of Chinese listed firms over the last decade as compared to firms operating in other global economies (e.g., Chan et al., 2018; Li, Liu and Scott, 2019). As far back as the early days of the establishment of the Chinese financial market, serial-related regulations and laws were developed to provide legislative endorsement for the use of stock pledging as collateral (the PRC Security Law, 1995; the PRC Guarantee Law, 1995). Unfortunately, though this regulatory framework originally aimed to facilitate shareholders' personal financing and to improve market mechanism and efficiency, it could be misused and even abused by the large shareholders and corporate insiders. As per the 2013 publication of "The Guidance on Stock Pledge Repurchase Transactions, Registration, and Settlement", security companies are permitted to participate in pledge activities as pledgees further expand the supply of credit and encourage shareholders to pledge their shares as collateral for personal financing. Meanwhile, regulation in the Chinese financial market requires Chinese listed firms to provide detail and timely disclosure of their shareholder's pledge of stocks which also provides excellent available data for empirical investigation. As the largest emerging market in the world, the Chinese stock market suffers from several impediments, including severe agency problems, weak minority shareholder protection, as well as an inefficient mechanism to oversee corporate governance (e.g., Claessens et al., 2000). Therefore, the Chinese stock market is an ideal context to conduct thorough empirical research to examine the economic consequence of the stock pledge activities.

In this paper, we focus on corporate acquisitions because they are among the biggest investment decisions that a company would ever make and have large impacts on the firm's growth and market value (Betton, Eckbo, and Thorburn, 2008). Moreover, controlling shareholder expropriation through merger and acquisitions by means of overpayments, related-party 
transactions as well as self-serving target selections is severe in emerging markets with weak investor protection and with listed firms with highly concentrated ownership (e.g., Bae et al., 2002; Thraya, 2015; Yang et al., 2019). Recently, this type of expropriation by the corporate insiders has raised much attention in the financial market of China by the government and regulatory institutions. $^{4}$

We develop the aggravated expropriation hypothesis which proposes that the controlling shareholder stock pledge would exacerbate the incentives of tunneling, leading to self-serving corporate takeovers and worse acquisition performance. Because the controlling shareholders are often the ultimate owners of the firms via the utilization of ownership pyramids and participation in top management (e.g., Shleifer and Vishny, 1997; La Porta et al., 1999), they are able to take advantage of their decisive voting power and make favorable corporate decisions for their own benefit which could potentially jeopardize the interests of other minority shareholders. When the controlling shareholders pledge shares, they transfer their cash-flow rights on the pledged stocks to loan providers ${ }^{5}$ while retaining the voting power of those pledged shares. As long as the stock price does not trigger the margin calls, the stock pledge would result in a further divergence between the cash-flow rights and control rights of the corporate insiders. More importantly, the stock pledge by the controlling shareholder is not a temporary behavior in the short term, but in fact, such pledge status typically remains for a prolonged period. ${ }^{6}$ Consequently, the further

${ }^{4}$ See the official conference press on February $27^{\text {th }}, 2019$ by the Chair YI Huiman of the China Securities Regulatory Commission (http://egs.stcn.com/live/detail?id=563) and also the media address on the Shenzhen Stock Exchange (http://www.21jingji.com/2019/2-28/1MMDEzNzhfMTQ3MzU1Mg.html).

5 According to The Guarantee Law of the People's Republic of China of 1995, "A pledgee has the right to collect the derivatives of the hypothecated assets". See the article 68 of the law (http://www.npc.gov.cn/wxzl/gongbao/1995-06/30/content_1480123.htm).

${ }^{6}$ The pledges in our sample are long-term, $81.08 \%$ of the firms remain stock pledge status in two years after the M\&A. For all firms in our sample, once a firm start to have controlling shareholder stock pledge, over $61.07 \%$ of 
divergence of ownership and control induces long-lasting entrenchment problem. The expropriation by the controlling shareholders could be aggravated either due to the exacerbated negative entrenchment effect brought by the relatively increased control rights (e.g., Stulz, 1988; Claessens et al., 2002) or to the weakened positive incentive effect because of the reduced cashflow rights (e.g., Morck et al., 1988; Claessens et al., 2002).

The prior literature suggests that firms subjected to severe agency problems on the controlling shareholder are more likely to make investment decisions, especially self-interested acquisitions (e.g., Jensen, 1986; Morck et al., 1990; Stulz, 1990; Harford, 1999; Bebchuk, Kraakman, and Triantis, 2000; Bae et al., 2002). To be more specific, by using M\&A transactions, the controlling shareholder could tunnel cash flow (Bae et al., 2002); achieve related party transactions (Cheung et al., 2006; Cheung et al., 2009); overpay in M\&A deals at the expense of minority shareholders to extract private benefits (Thraya, 2015; Thraya and Hamza, 2019); gain political benefits from the local government (Yang et al., 2019). Thus, the aggravated expropriation hypothesis predicts that firms with stock pledges by the controlling shareholders are more likely to conduct acquisition subjected to the expropriation but receive worse market reaction.

Empirically, we do find that the aggravated expropriation hypothesis dominates in the observations of our sample. Firstly, we find that firms have increased acquisition activities after their controlling shareholders pledge stock. However, acquisition deals initiated by pledging firms ${ }^{7}$ obtain lower announcement returns. This result is consistent with the prediction that stock pledges made by the controlling shareholder would induce agency problems, increase incentives of expropriation and lead to self-serving acquisitions. Our results are robust to alternative variable

the firms have pledge status to the end of the year in our sample. $62.8 \%$ firms remain stock pledge status for overt eight years.

${ }^{7}$ In this paper, we also use pledging firms to refer firms with controlling shareholder stock pledge. 
measures, samples, and fixed effects. To mitigate the endogenous concerns, we conduct two additional analyses using the instrumental variable approach, as well as the difference in differences tests. Exploring the mechanism of the market reaction to such acquisitions, we further find that the controlling shareholder stock pledge is positively related to the takeover premiums, thereby indicating that corporate decision-makers systematically overpay in those transactions. We also document that those acquisitions are more likely to be related party transactions. These pertinent results show that controlling shareholders of the pledging firms tend to exploit corporate acquisition as a tool of extracting private benefits at the expense of minority shareholder interests. Cross-sectionally, we document that the relationship between the stock pledge and returns is stronger for non-SOEs and firms with high-level free cash flows. Lastly, we find that firms with controlling shareholders engaged in stock pledging underperform in the long run as reflected by lower ROAs and a greater likelihood of goodwill impairment after the acquisitions. Overall, we find that stock pledge increases the propensity of corporate takeovers but such acquisitions are subjected to the tunneling and expropriation.

The contributions of this paper are three-fold to the literature. Firstly, we extend the growing research on the share pledge by documenting its effect on corporate real investment decisions and the long-term economic consequences. The unique characteristic of the stock pledge has attracted extensive attention from the academia. Prior studies mainly focus on the effect of stock pledge on equity risk (e.g., Chen et al., 2018; Dou et al., 2019), firm valuation (Dou et al., 2019; Li, Liu, and Scott; 2019), corporate innovation (Pang and Wang, 2020), dividend policy (Li, Zhou. Yan, and Zhang, 2019), share repurchase (Chan et al., 2018) and executive compensation (Ouyang et al., 2019). However, only limited studies have been conducted to investigate the effects of controlling shareholder stock pledge behavior on corporate real-investment decisions such as 
corporate takeovers and associated performance. By documenting a causal effect of share pledging on self-serving M\&A decisions, our findings have significant policy implications regarding minority shareholder protection and the debate on the propriety of the stock pledge.

Secondly, we further contribute to the literature on the merger and acquisition. While the M\&A literature has investigated the antecedents of acquisition behavior in some aspects of the corporate insider, including CEO compensation (e.g., Agrawal and Walkling, 1994; Sanders, 2001; Deutsch, Keil, and Laamanen, 2007), managerial hubris (e.g., Hayward and Hambrick, 1997; Malmendier and Tate, 2008), executive networks (e.g., Haunschild, 1993; Haunschild and Beckman, 1998; Westphal, Seidel, and Stewart, 2001), acquisition experience (e.g., Haleblian, Kim, and Rajagopalan, 2006), the effect of the controlling shareholder stock pledge on corporate acquisition decision and performance is still unexplored. Hence this paper provides an innovative angle to explain the incentive of corporate takeovers, and we find that stock pledge made by the controlling shareholder is one of the important antecedents for corporate acquisition which is still uncovered in the prior literature.

Last but not at least, we make contributions to the vast literature exploring the economic consequences of agency problems and controlling shareholder expropriation. In many developed financial markets, agency problems mainly present in the form of a conflict of interests between shareholders and the corporate manager. Therefore, most of the research examines the agentprincipal problem, as well as managerial self-interest as determinants of motivation for M\&A activity. However, the agency conflict between controlling and minority shareholders dominates in the emerging economies including China (e.g., La Porta et al., 1999; Claessens et al., 2000). Due to such agency problems, the corporate acquisition is unlikely to be purely driven by the economic incentive (Yang et al., 2019). Therefore, we provide new evidence that even controlling 
shareholder's personal behavior, i.e., share pledging, would affect important corporate decisions. Ultimately, our findings deepen the understanding that controlling shareholders could expropriate the interests of minority shareholders through the mechanism of corporate acquisitions.

The rest of the paper proceeds as follows: Section 2 discusses the related literature and presents the development of our main hypothesis; Section 3 introduces the data and sample as well as descriptive statistics; and the empirical results are shown in Section 4. In Section 5, we conclude the paper.

\section{Literature review and hypotheses development}

\subsection{Related literature}

\subsubsection{Stock pledge, agency problem, and firm value}

There is a growing body of research providing evidence that insiders' stock pledge is associated with equity risk, agency problem, and can affect the firm value. By analyzing manually collected pledging data from US firms against an exogenous shock to the credit market lending capability (2008 financial crisis), Anderson and Puleo (2020) find a significant causal effect between insider pledge behavior and firm-specific risk. There are also antecedent studies using stock pledge data in Taiwan and attract the following attention in the literature. For instance, based on a sample of Taiwanese banks, Chen and Kao (2011) find that stock price volatility is positively related to bank insiders' stock pledges. They further document such pledge activity as being negatively associated with firm value. Chan et al. (2018) find that firms controlling shareholder stock pledges are more likely to engage stock repurchase, especially when they face margin call pressure. Wang and Chou (2018) find that stock pledging firms exhibit higher stock returns than 
those of non-pledged firms after a legal improvement to protect minority shareholders in Taiwan. They conclude that such regulatory amendments could mitigate the agency problem induced by the stock pledge. Dou et al. (2019) find that the negative causal impact of stock pledges on shareholder wealth is due to the increased crash risk of firms and reduced corporate risk-taking. Furthermore, relying on the data of listed Chinese firms that make considerable contributions, several studies have examined the effect of insider's stock pledges on corporate investment decisions, executive compensation, and payout policies. To illustrate, Pang and Wang (2020) find that both the existence and the quantitative level of the stock pledge by the firm's controlling shareholder are negatively associated with corporate innovation outputs, such as the number of patents and patent citations held by a firm. They further argue that after the stock pledge is made, the fear of losing control discourages the firm's controlling shareholders to make corporate decisions prone to R\&D investment in an attempt to avoid innovation failure. Ouyang et al. (2019) contend that stock pledge initiated by the corporate insider exacerbates agency problems and find that insiders' stock pledges are negatively associated with executive pay-for-performance sensitivity. Li, Zhou, Yan, and Zhang (2019) find that firms with shares pledged by controlling shareholders have fewer cash dividend payments as compared to firms without such a stock pledge. They also find that firms tend to pay fewer cash dividends after their controlling shareholders pledge the shares, further concluding that such a decrease in the tendency of dividend payout reflects the controlling shareholders' strong incentive to transfer cash and assets to expropriate minority shareholders. From the accounting perspective, Singh (2018) and DeJong, Liao, and Xie (2020) provide evidence that stock pledge by the controlling shareholder encourages a firm's earnings management by using the S\&P 1500 firms and Chinese listed firms respectively. 
However, the extant literature exhibits mixed results with regard to the fundamental effect of stock pledging on the value of the firm. While some of the aforementioned studies show that stock pledge is negatively associated with firm value, a few research provide opposite evidence to this assertion. Using the data from listed firms in the US, Chen, and Hu (2018) show that the announcement of insider pledging has no significant impact on shareholders' wealth and that oneyear abnormal stock returns after the disclosure is even positive. Li, Liu, and Scott (2019) use a sample of Chinese listed firms and document a positive association between share pledges by the largest shareholder and firm value. They provide additional evidence, consistent with the signaling explanation, for such a positive correlation reflecting the controlling shareholder's confidence in a firm's operation, profitability, and the sustainability of its stock price in the future. In short, the extant literature exhibits mixed results on the properties of the stock pledge by the controlling shareholder.

\subsubsection{The divergence of ownership and control, controlling shareholder expropriation and corporate takeover activities}

Our study also relates to the literature examining the controlling shareholder expropriation on corporate resources and investments. Agency problems arise typically due to the conflicts of interests among the parties involved in corporate ownership, operation and financing. While the agent-principal problem (type I agency problem) focuses on the conflict of interests between the manager and the shareholders (e.g., Jensen and Meckling, 1976; Fama and Jensen, 1983a\&b;), the principal-principal problem (type II agency problem) contends that the conflicts between controlling shareholders and outside minority investors are more prevalent and severe among firms with high concentration of ownership and in countries with poor investor protection (e.g., Shleifer 
and Vishny, 1997; La Porta et al., 1999; Claessens et al., 2000). The prior literature suggests that such a wedge between control and ownership would induce severe agency problems and expropriation over the minority shareholders by the controlling shareholders. Shleifer and Vishny (1997) suggest that large shareholders, when having superior control over the firm, would prefer to make corporate decisions to generate private benefits of control that are not shared by other minority shareholders. Zingales (1994) finds that there is a large pricing premium in the shares associated with voting rights and argues that such premium could attribute to the private benefits of control brought by the concentrated ownership. Bebchuk, Kraakman, and Triantis (2000) also propose that dispersion between controlling shareholders' voting rights and cash-flow rights could create a substantial magnitude of agency costs. Stulz (1988) argues that concentrated ownership also gives corporate insiders more discretion to misallocate resources. Similarly, Morck, Wolfenzon, and Yeung (2005) suggest that such divergence can result in inefficient investments when controlling shareholders seek their own private benefit as generated by the related investment. Moreover, La Porta et al. (2000b) argue that controlling shareholders can determine the selection of the managers due to their excessive voting power. Consequently, explicit collusion could exist between manager and large shareholders over the minority shareholders (Zhang et al., 2014).

Further, we discuss one particular corporate activity, namely, the merger and acquisition, to serve our main interest in this study. A large body of empirical studies documents that bad corporate acquisition decisions can be driven by the self-interests of the firm's insider (e.g., manager, controlling shareholder) and eventually such agency-related takeovers destroy the shareholder's wealth for outside minority investors. Amihud and Lev (1981) find that firms engage in the conglomerate merger because managers tend to utilize the diversification strategies to increase the survival potential of the corporation and reduce their own risks of losing the current 
job. They suggest that such managerial behavior is consistent with the agency cost model. Jensen (1986) suggests that the excessive free cash flows due to the industrial boom would exacerbate the agency costs and result in empire-building overinvestment and failed diversification programs due to the lack of relevant knowledge and experience. Consistent with Jensen (1986)'s prediction of free cash flow hypothesis, Lang et al. (1991) and Harford (1999) show that acquisitions initiated by firms with more cash reserves are more likely to be value-decreasing. Using a sample of U.S. acquisitions between 1975 and 1987, Morck, Shleifer and Vishny (1990) also suggest that the manager would prefer acquisition opportunities that bring substantial personal benefits despite sacrificing the market value of the firm. Moreover, Bae et al. (2002) provide evidence that controlling shareholders would make acquisitions through affiliated firms to increase their own wealth while leaving the minority shareholders to lose. In sum, there is adequate empirical evidence showing that the agency problem affects corporate acquisition decisions and outcomes.

\subsection{The aggravated expropriation hypothesis}

Previous studies suggest that the entrenchment effects induced by excess control rights would lead controlling shareholders to engage in various forms of expropriation such as tunneling and misallocating resources. Consistent with this tranche of studies, the aggravated expropriation hypothesis suggests that, due to the divergence of cash-flow rights and voting rights caused by the prolonged stock pledge, the controlling shareholder has more incentive but lower costs to expropriate, driving self-interested acquisitions while sacrificing the interests of minority shareholders.

The stock pledge activities among Chinese listed firms are prevalent since controlling shareholders typically pledge the large proportion of their shares and such pledge status would 
remain for a long duration. In our sample among the pledging firms, controlling shareholders pledge $59.7 \%$ of the total shareholding on average and once a firm starts to have controlling shareholder stock pledge, over $61.07 \%$ of the firms have pledge status to the end of the year in our sample. $62.8 \%$ of firms remain stock pledge status for overt eight years. Stock pledge activities can aggravate the expropriation because when controlling shareholders pledge their shares for a prolonged period, they transfer cash-flow rights on the pledged stocks to the pledgee. ${ }^{8}$ As long as the pledge does not default, pledgers still retain their voting rights (Li, Zhou, Yan, and Zhang, 2019). The relatively excessive control rights enable controlling shareholders to take self-serving corporate policies while lower cash-flow rights would lead to entrenchment problems and increase the incentives of the large shareholder to expropriate (Bozec and Laurin, 2008). Therefore, a longterm stock pledge would result in prolonged excessive voting rights of controlling shareholders, thus encouraging them to pursue private benefits at the expense of minority shareholders (Bozec and Laurin, 2008; Wang and Chou, 2018; Zhao et al., 2019; Ouyang et al., 2019; Li, Zhou. Yan, and Zhang, 2019). More specifically, the controlling shareholders who pledge their shares maintain their decisive voting power on important corporate decisions but incur less risk to bear the residual claims generated by the operating cash flows from the firm. Previous studies suggest that the payoff structure of stock pledge is "call option like" where controlling shareholders reap benefits on their cashed out capital and unlimited potential appreciation on the stock but the downside risk is effectively hedged by transferring the obligations to the capital providers such as banks and security firms (Dou et al., 2019; Pang and Wang, 2020). Moreover, controlling shareholders typically have a large proportion of their stock pledged and long-lasting pledge status once they

${ }^{8}$ One may have concern that the controlling shareholder could time or decrease the dividend payout. However, as found by Li, Zhou, Yan, and Zhang (2019), pledging firms have 19\% payout ratio which is still substantial and comparable (though less) to non-pledged firms which have $22 \%$ payout ratio. 
initiate pledging activities. Consequently, the costs of conducting expropriation for self-interest is reduced in the long run, and controlling shareholders are thus more prone to spend corporate resources to generate private benefits of control that are not shared by minority shareholders even if such actions are not profit-maximizing (Shleifer and Vishny, 1997). As a result, the stock pledge exacerbates entrenchment effects and weaken the positive incentive effect on the controlling shareholder (Claessens et al., 2002) in the long horizon.

Controlling shareholder expropriation in the form of acquisitions is common in emerging markets with weak investor protection and with highly concentrated ownership, especially among the listed firms in China (Yang et al., 2019). The extant literature suggests that controlling shareholders exploit acquisitions in many ways to pursue private benefits. First, the controlling shareholder could use M\&A transactions to tunnel the cash flows among the subsidiaries within the firm or transfer the wealth out of the current corporation (e.g., Johnson et al., 2000; Bae et al., 2002). Secondly, when the related party transaction is involved in the acquisition, the acquirer takes advantage of transfer prices to facilitate transactions with certain entities affiliated to the controlling shareholder (Cheung et al., 2006; Cheung et al., 2009). Thirdly, corporate acquisitions in China could also provide potential opportunities for controlling shareholders to gain political benefits from the local government (Yang et al., 2019). Fourthly, controlling shareholders can utilize the acquisitions to exercise their discretion on corporate activities to divert resources (e.g., cash) away from the distribution to other shareholders (Harford, 1999; Bhaumik and Selarka, 2012). Fifthly, the prior literature contends that controlling shareholders overpay in M\&A deals at the expense of other stakeholders to satisfy their private benefits (Thraya, 2015; Thraya and Hamza, 2019). Last but not at least, in countries where nepotism is a common practice, managers are closely related to the family of the controlling shareholder (e.g., Shleifer and Vishny, 1997; La 
Porta et al., 1999). When controlling shareholders possess excess control rights, they may collude with managers to expropriate the minority shareholders (Zhang et al., 2014). Thus, such rentsharing behavior among controlling shareholders and managers would alter the corporate decision prone to takeovers for the benefit of the manager's own job security (e.g., Amihud and Lev, 1981) or empire-building to increase the firm size for excessive compensations (e.g., Jensen, 1986).

We are not unaware that there are other reasons to believe that stock pledge could decrease the incentive of conducting corporate acquisition. For instance, Dou et al., (2019) suggest that margin call pressure after the stock pledge increases the firm's crash risk and creates the fear of losing control among the corporate insiders. To avoid unexpected fluctuation in the stock price, controlling shareholders' reduced risk-taking preference may result in a decline in the level of M\&A activity. However, in the practice, the controlling shareholder can avoid the forced sale of their pledged shares by supplementing more assets to collaterals and negotiating with the pledgee to extend the pledging duration. ${ }^{9}$ Thus, the negative effect of stock pledge on the acquisition motivation is unlikely to manifest compared to the prolonged expropriation incentives.

In short, pledge-induced entrenchment resulted from the prolonged divergence between controlling shareholders' cash-flow rights and voting rights drive expropriation over minority shareholders in the preference of self-interested acquisitions to pursue private benefits. Thus, the aggravated expropriation hypothesis firstly predicts that firms with the stock pledge by their controlling shareholders are more likely to conduct merger and acquisitions subjected to tunneling. Moreover, the previous studies also provide evidence that the market reacts less favorably and that the acquirer typically experiences negatively announcement returns when the acquisitions are

\footnotetext{
${ }^{9}$ See official media address from both Shanghai Stock Exchange (http://www.sse.com.cn/aboutus/mediacenter/hotandd/c/c_20180626_4579779.shtml) and the Shenzhen Stock Exchange (http://www.szse.cn/aboutus/trends/news/t20180626_552064.html).
} 
suspected as self-serving takeovers (e.g., Lewellen, Loderer, and Rosenfeld, 1985; Morck, Shleifer, and Vishny, 1990; Lang, Stulz, and Walkling, 1991; Berkovitch and Narayanan, 1993; Harford, 1999; Harford et al., 2012). Therefore, the expropriation hypothesis also posits that acquisitions driven by the controlling shareholder's own interests tend to have bad quality and unfair payment in the deal, which in return, receives the negative market reaction when pledging firms announce their decision of acquisition. Collectively, although tension exists in the research question, on balance, we state our primary hypothesis as follows:

The aggravated expropriation hypothesis: Stock pledge is positively related to the level of corporate acquisition activity but negatively related to the announcement returns of these acquisitions.

\section{Data and descriptive statistics}

\subsection{Sample construction}

Our initial sample includes all firm year observations of A-share Chinese listed companies from 2003-2017. All the financial information is taken from the China Stock Market and Accounting Research (CSMAR) database. Our sample begins in 2003 because CSMAR starts to report pledge information of the top 10 shareholders in that year. Following the prior literature, we exclude firms in the financial sector. All the continuous variables are winsorized at $1 \%$ and $99 \%$ levels to mitigate the concern of the extreme values. We obtain M\&A data from CSMAR Chinese Listed Firms' M\&A and Asset Restructuring Research Database. It worth noting that our M\&A sample is from 2004-2018, one year ahead of pledge and other controls. 
We use the following criteria to filter our M\&A sample: (1) acquirers would be A-share publicly-listed companies; (2) transaction type is limited to mergers, tender offers, and acquisitions of assets; (3) we exclude the observations with more than one deal announced during one year to mitigate the concern of contamination issue (e.g., Zhou et al., 2015; Bi and Wang, 2018); and (4) the acquirers must have necessary data in our first M\&A tendency regression. Our final M\&A sample includes 6,553 deals. Because in the CAR (cumulative abnormal return) analysis, we need deal level information as well as data on the preannouncement stock return to estimate the market model, our sample further drops to 5,532. We include both complete and failed deals in the sample following Yang et al. (2019). However, in the long-term tests, i.e., post-M\&A accounting performance and goodwill impairment, we only include complete deals.

\subsection{Summary statistics}

Table 1 presents the summary statistics for the key variables of the full sample and subsamples for acquirers and non-acquirers. A detailed definition of variables is provided in Appendix A. On average, $37.1 \%$ controlling shareholders from the acquires pledge the shares during the sample period, while only $30.5 \%$ of the non-acquirers do so. The difference is significant at $1 \%$ level, indicating that pledging firms are more likely to conduct M\&A transactions.

Firm size is comparable between acquirers and non-acquirers, with means (median) of 21.8 (21.6). Acquirers show better performance than non-acquirers in terms of both stock return and ROA. The mean (median) annual return is $39.6 \%(10.4 \%)$ for acquirers and $29.3 \%(2.6 \%)$ for nonacquirers. The mean (median) ROA is $3.9 \%$ (3.8\%) for acquirers and $3.2 \%(3.4 \%)$ for nonacquirers. With regards to liquidity, acquirers hold more cash and have lower leverage compared to non-acquirers, which is consistent with the literature which indicates that firms with greater 
liquidity have a stronger propensity to conduct M\&A (e.g., Yang et al.,2019). Acquirers and nonacquirers have a similar percentage of intangible assets and capital expenditures. Acquirers have slightly higher Tobin's Q with the mean (median) of 2.74 (2.10) than non-acquirers (mean: 2.61; median:1.93). The controlling shareholders hold, on average, $35.7 \%$ of shares in acquiring companies and $36.5 \%$ in non-acquiring companies. In both acquiring and non-acquiring firms, there are about nine directors on the board, and $37 \%$ of them are independent board members. Moreover, $41.6 \%$ of the acquirers are state-owned enterprises, while $49.9 \%$ percent of the nonacquirers are SOEs. The percentage of CEO duality is higher for acquirers (23.2\%) than nonacquirers (20.5\%).

In terms of deal characteristics, $83.9 \%$ deals are paid by pure cash while $8.2 \%$ of deals are paid by cash-related payment methods. Takeover premium has a mean of $48.9 \%$ and a median of $0.00 \%$. The mean (median) of 7 day and 11 day cumulative abnormal returns are $2.0 \%(0.2 \%)$ and $2.2 \%(0.2 \%)$ respectively. $37.9 \%$ of M\&A deals are related party transactions. $11.5 \%$ deals belong to significant deals. On average, the deal value accounts for $23.9 \%$ percent of the acquirer's total assets. The mean (median) stock run-up for 200 trading days ending 61 days before the deal announcement is $23 \%$ (4.0\%). Most of the firms (93.5\%) finally complete the deal.

\section{Controlling shareholder stock pledge and firm M\&A tendency}

We first study how controlling shareholder stock pledge affects the M\&A tendency. To investigate the relationship, we estimate the following model:

$\operatorname{Prob}\left(M \& A_{i, t+1}=1\right)=a+b_{1}$ Pledge_Dummy $_{i, t}+b_{2}$ Size $_{i, t}+b_{3}$ Annual Return $_{i, t}+b_{4}$ Cash $_{i, t}+b_{5} R O A$ ${ }_{i, t}+b_{6}$ Intangible $_{i, t}+b_{7}$ Leverage $_{i, t}+b_{8}$ Capital Expenditure ${ }_{i, t}+b_{9}$ Tobin's $_{Q_{i, t}}+b_{10}$ Blockholders 


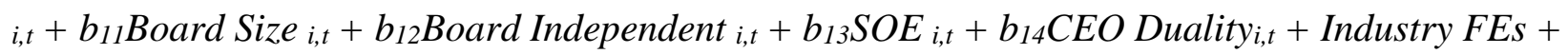
Year FEs + Province FEs $+\varepsilon_{i, t}$

where $i$ represents the firm, and $t$ represents the year. The dependent variable, $M \& \mathrm{~A}_{\mathrm{i}, t+1}$, is a dummy that equals 1 if firm $i$ announces a merger and acquisition in year $t+1$, and 0 otherwise. The variable of interest, Pledge_Dummy i,t, is a dummy that indicates the existence of controlling shareholder pledge at the end of the year. The aggravated expropriation hypothesis predicts $b_{1}$ to be positive.

We include a set of control variables in the regression following the prior literature. Size is the natural logarithm of total assets. Annual Return is the annual stock return for the acquirer before the corporate acquisition. Cash is the ratio of cash and cash equivalent to the firm's total assets. ROA is the net income divided by total assets. Intangible equals to intangible assets divided by total assets. Leverage equals total debts divided by total assets. Capital Expenditure is the capital expenditure scaled by total assets. Tobin's Q equals the sum of the market value of equity and total liabilities divided by total assets. Blockholders is the percentage of shares owned by the controlling shareholder. Board Size equals to the total number of members on the board of directors. Board Independent is the ratio of the independent board members to the board size. SOE is a dummy variable that equals one if the firm is state-owned in a given year and zero otherwise. CEO Duality is a dummy that equals one if the CEO is also the chair of the board and zero otherwise.

We add industry fixed effects to control for industry-specific characteristics that affect M\&A tendency. We use the CSRC 2012 Classification to define the industry. CSRC Classification includes one letter and two digits. We also include year fixed effect to control for time-invariant differences. Because there is a huge variation of economic conditions and financial developments across provinces in China, it is plausible that the unique characteristics of the province could affect 
both share pledge and M\&A decisions. Therefore, we also add province fixed effects following Yang et al. (2019). The standard errors are clustered at the firm level. We estimate equation (1) using the probit model.

Table 2 shows the regression results. The coefficient on our variable of interest-stock pledge dummy is positive and significant at $1 \%$ level, showing that firms with the controlling shareholder pledging their shares are more likely to announce an M\&A in the following year. The results are in line with the prediction that firms with the stock pledge by their controlling shareholders are more likely to conduct merger and acquisitions.

\section{Stock pledge and announcement return}

\subsection{Baseline regressions}

To investigate whether stock pledge by the controlling shareholders affects the value of the acquiring company, we use the event study method and estimate the following OLS model:

CAR $[-3,+3]_{i, t+1} /$ CAR $[-5,+5]_{i, t+1}=a+b_{1}$ Pledge_Dummy $_{i, t}+b_{2}$ Size $_{i, t}+b_{3}$ Annual Return $_{i, t}+b_{4}$ Cash $_{i, t}+$ $b_{5}$ ROA $_{i, t}+b_{6}$ Intangible $_{i, t}+b_{7}$ Leverage $_{i, t}+b_{8}$ Capital Expenditure $_{i, t}+b_{9}$ Tobin's $_{Q_{i, t}}+b_{10}$ Blockholders $_{i, t}$ $+b_{11}$ Board Size $_{i, t}+b_{12}$ Board Independent $_{i, t}+b_{13}$ SOE $_{i, t}+b_{14} C E O$ Duality $_{i, t}+b_{15}$ Related $_{i, t+1}+$ $b_{16}$ Significant $_{i, t+1}+b_{17}$ Relative Size $_{i, t+1}+b_{18}$ Runup_stock $_{i, t+1}+b_{19}$ Cash Payment $_{i, t+1}+b_{20}$ Cash Mixed $i, t+1+$ Industry FEs + Year FEs + Province FEs $+\varepsilon_{i, t}$

CAR $[-3,+3]($ CAR $[-5,+5])$ is the cumulative abnormal stock return over the 7 -day (11day) event window centered on the acquisition announcement date. We estimate the parameters of the market model using 200 trading days ending 61 trading days prior to the deal announcement date. CARs are calculated using the estimated parameter for different event windows. 
Compared to equation (1), we further control for deal characteristics. Related is a dummy that equals 1 if the deal is a related party transaction, and 0 otherwise. Significant is a dummy that equals 1 if the deal is a significant transaction ${ }^{10}$, and 0 otherwise. Relative Size is the ratio of deal value to the acquirer's total assets. Runup_stock is the daily buy and hold Shanghai and Shenzhen value-weighted stock returns over the period beginning at 260 days and ending at 61 days prior to the announcement date. Cash Payment is a dummy that equals one if the payment is pure cash, and zero otherwise. Cash Mixed is a dummy that equals one if the payment involves cash and other types of payment, and zero otherwise.

Table 3 presents the OLS regression results for CAR. As shown in column (1) and (2), after controlling for the various acquirer and deal-specific factors, the coefficients on pledge dummy are still negative and significant. The coefficient of $-0.008(-0.009)$ suggests that the pledging firms experience $0.8 \%(0.9 \%)$ more negative $\mathrm{M} \& \mathrm{~A}$ announced returns during the 7-day (11-day) window as compared to non-pledging firms. The negative coefficients support the aggravated expropriation hypothesis that pledging companies experience more negative market reactions to the M\&A deals.

The coefficients on other controls are generally consistent with the literature. Similar to Moeller et al. (2004), we find a negative relationship between CAR and Size. As Masulis et al. (2007), our results also show that acquirers with more positive price run-up before announcements are associated with lower announcement returns. While the positive coefficients on Significant and Relative Size and the negative coefficient on Cash payment and Cash Mixed are opposite to the U.S. research, it is consistent with Chinese literature (e.g., Liu et al., 2016; Yang et al., 2019). The

${ }^{10}$ Also known as major deals which are large M\&A deals with the deal value exceeds 50 percent of the listed firm's size. See the appendix of Zhang et al. (2019) for detailed discussion. 
results show that Chinese investors have a higher expectation on M\&A deals with larger size and noncash payments.

\subsection{Robustness tests}

In order to make sure that our results on the relationship between CAR and pledge is robust, we conduct a series of additional tests using alternative definition of stock pledge, fixed effects and sample selections. Table 4 reports the results. Our first robustness test uses the ratio of the number of shares pledged to the total number of shares held by the controlling shareholder (Pledge_Percent) as the independent variable. Pledge_Percent measures the degree of further separation of cash-flow rights and control rights by the controlling shareholder arising from share pledge. Pledge_Percent has a mean of 0.198 and a standard deviation of 0.3298. As shown in column (1) ((2)), one standard deviation increase in the percentage of share pledged decreases the 7-day (11-day) announcement return by $0.5 \%(0.6 \%)$.

Secondly, we conduct the analysis with firm and year fixed effects to further control for omitted characteristics of acquirers that could affect both pledge and M\&A announcement return. Specifically, we are comparing the deal announcement return of the acquirer when its controlling shareholder does not pledge the share, and the announcement return from the same acquirer when the controlling shareholder pledges the share. As not all firms conduct more than one acquisitions during the sample period, the sample drops to 4,655. The results in column (3) and (4) are similar to the baseline regressions, which suggests that the controlling shareholder expropriation is exaggerated within the firm after their controlling shareholder pledges the shares. 
Lastly, we test whether the results hold in different samples. In column (5) and (6), we drop the special treatment (ST) stocks, i.e., firms report losses for two consecutive years. As shown in Table 4, the results remain quantitatively unchanged after dropping those firms. Next, we exclude the small transactions with the deal value of less than $1 \%$ of the acquirer's total assets, thereby decreasing the sample to 3,822. Column (7) and (8) suggest that the negative relationship between pledge and CAR is still robust. To mitigate the concern that SOEs have more government interference and the potential differences in the purpose of share pledge between the two types of firms, we exclude the SOEs. The results from column (9) and (10) confirm that the negative relationship between CAR and pledge still hold in the non-SOE sample alone. It worth noting that all previous tests are based on the sample with only one deal announced during one specific year. In column (11) and (12), we expand the sample to include observations with multiple deals during the year. However, we still exclude the sample with multiple deals during the $[-5,+5]$ window to mitigate the contamination issue. The results are still significant and comparable to the baseline. ${ }^{11}$

\subsection{Endogeneity tests}

Our primary tests show that share pledge is negatively correlated with the M\&A announcement returns. We notice that endogenous issues might exist in our study: (1) unobserved omitted variables could drive both share pledge and negative market reaction (2) firms with worse M\&A performance could be more likely to pledge the shares. To further mitigate the endogenous

${ }^{11}$ We also conduct the robustness tests for M\&A tendency, the results are shown in Appendix B. 
concern, we perform two sets of tests: the difference in differences approach and the instrumental variable approach following the prior literature (e.g., Pang and Wang, 2020) ${ }^{12}$.

\subsubsection{Difference in Differences Approach}

In this section, we conduct the difference in differences (DID) tests by utilizing a regulatory change in 2013, i.e., the publication of "The Guidance on Stock Pledge Repurchase Transactions, Registration, and Settlement”. Before 2013, shareholders can only pledge shares to banks and trust firms. The 2013 rule further permits security companies to participate in pledge activities. Therefore, shareholders have broader ways to pledge their shares as collateral after 2013. Besides, security firms tend to have lower interest rates and fewer restrictions on the loan usage (Meng et al., 2019). Therefore, the regulation change encourages the share pledge, especially among shareholders who have difficulties in personal financing previously. On the other hand, this rule should be unrelated to the firm acquisition decisions as the primary objective of this rule is to regulate share pledge.

We firstly identify the firms that are affected mostly by this rule as the treatment sample. Our primary treatment group includes all firms whose controlling shareholders do not pledge the shares during the pre-regulation period (2011 and 2012) but pledge the shares during the postregulation period (2014 and 2015). We use the 4-year window around the regulation (2-year pre and 2-year post period) to mitigate the concern that the shareholders coincidently alter their pledging decision after this regulatory change. The primary control group includes all firms whose controlling shareholders do not pledge during the whole 2011-2015 period. We regard those firms as unaffected by the regulatory change. We further conduct a propensity score matching to make

\footnotetext{
12 The endogeneity tests on M\&A tendency are presented in Appendix D and E.
} 
sure that the treatment and control are comparable. To be more specific, we firstly run a probit regression of treatment dummy on all the controls in the M\&A tendency regression, including the industry, year, and province dummies. Then we use the predicted propensity score to select one control firm for each treatment firm with the nearest score from the same industry, year, and province. Finally, we derive 119 pairs. Yet as not all firms engage in M\&A activities during the window, our final sample drops to 132 firms (71 treatment firms and 61 control firms) in the CAR regressions.

We conduct our DID tests using the period from 2011 to 2015. We exclude observations in 2013, which is the event year. Post is a dummy that equals 1 if the observation belongs to the post-regulation period, and 0 otherwise. Treatment is a dummy that equals 1 if the firm is from the treatment group, and 0 otherwise. We report the results in Table 5. The coefficient on Treat*Post is negative and significant, indicating that the regulation which encourages the stock pledge activities would further induce agency problem reflected in more negative CARs experienced by the acquirer ${ }^{13}$.

To further confirm that we have adequately identified the stock pledge shock from the 2013 regulation change, we select another year other than 2013 as a pseudo mandate year and re-estimate the DID model. We conduct 2 placebo tests. For the pre-2013 period, we use 2010 as the pseudo event year, whereby Post is a dummy variable that equals 1 if the observation is after 2010, and 0 otherwise. Second, for the post-2013 period, the pseudo mandate year is set as 2016 so that Post equals one for 2014-2015 and zero for 2016-2017 ${ }^{14}$. The results are presented in Appendix C. The

\footnotetext{
${ }^{13}$ The DID tests include the same fixed effects as the baseline regressions. We also tried to control for the firm and the year fixed effects and find consistent results.

${ }^{14}$ Since the post-2013 period only includes four years, the pseudo post period also includes year 2016, which is also the pseudo event year.
} 
coefficients of Post*Treat for all four columns are insignificant and even positive indicating that this regulation results in significant change in the behaviour of controlling shareholder stock pledge for the treatment firms.

\subsubsection{Instrumental variable approach}

Our second endogeneity test adopts the instrumental variable approach. Following Pang and Wang (2020), we construct the instrument, Pledge_Percent (peer), as the average percent of shares pledged by the controlling shareholders from the peer companies operating in the same industry and located in the same province. Firms from the same industry have a similar operation environment and financing demand. Besides, we require the peers to be located in the same province because economic conditions and local policy varies across provinces. We predict the amount of the firm's peer pledging can represent the general level of pledging activity within the firm's industry and location. On the other hand, the M\&A announcement return should be unrelated to the peer pledge.

The first column in Table 6 shows the first stage regression ${ }^{15}$. The dependent variable, Pledge_Percent, is the percentage of shares pledged by the controlling shareholders. All other controls are the same as equation (1). We also include industry, year and province fixed effects. The second stage regression results in column (2) and (3) are consistent with the baseline ${ }^{16}$.

It is possible that firms from the same industry and geographic clustering have similar operation outcomes, e.g., M\&A decisions. Pang and Wang (2020) solve this problem by only include the non-event firms to construct the instrument. Following their spirit, we further exclude

\footnotetext{
${ }^{15}$ The first stage omits the deal level controls of the second stage.

${ }^{16}$ The sample in column (2) and (3) drop to 4,336 because some firms do not have peers operating in the same industry and locating in the same province.
} 
peers with M\&A activities during the $[-1,+1]$ year window when calculating the instrument ${ }^{17}$. The results are presented in column (4) - (6) The same further drop to 3,299. However, the negative relationship between CAR and pledge is still significant.

\subsection{Channel tests}

Our previous analyses suggest that share pledge by the controlling shareholder leads to more M\&A activities but a worse market reaction. As with the aggravated expropriation hypothesis we discussed in section 2.2 , there are several mechanisms driving the impediment effect of share pledge on announcement return. In this section, we use multivariate regressions to further explore the potential mechanisms, including overpayment in the deals and related party transactions.

The exacerbated agency problem caused by share pledge increases the likelihood of expropriation by the controlling shareholder. They tend to overpay in the M\&A deals to pursue their own private benefits at the expense of minority shareholders. Besides, the controlling shareholders have fewer positive incentives to maximize the firm value due to the further divergence of voting rights and cash-flow rights. Thus, pledging firms are more likely to pay higher acquisition premiums. To test this conjecture, we examine the relationship between takeover premium and stock pledge. Premium equals to the trading value of the target divided by the estimated value minus one. Column (1) in Table 7 shows that the coefficient of the stock pledge

${ }^{17}$ Non-M\&A firms only account for about $10 \%$ of the full sample. Therefore, we only exclude peers with M\&A activities during the $[-1,+1]$ year window. 
is positive and significant at $5 \%$ level ${ }^{18}$. Regarding economic significance, on average, pledging firms pay $23.4 \%$ more premium than non-pledging firms.

Related party transaction is widely recognized as a way of controlling shareholder expropriation and tunneling (e.g., Bae et al., 2002). We expect that pledging firms have a greater tendency to engage in related party acquisitions. We regress the related party transaction dummy on share pledge using the M\&A sample with the probit model using the same controls as equation (1). As shown in Table 7 column (2), the coefficient on Pledge_Dummy is positive and significant at the $10 \%$ level. In sum, our results on takeover premium and related-party transactions indicate that acquisitions made by the pledging firms are indeed subjected to the self-serving target selections and private benefits extraction, consistent with our expropriation hypothesis.

\subsection{Cross-sectional tests}

In this section, we further conduct a series of cross-sectional tests to deepen the understanding of the relationship between share pledge and M\&A announcement return.

Our first cross-sectional test focuses on differences between the SOE firms and non-SOE firms. As indicated in some previous studies (e.g., Li et al., 2019), the government imposes stricter restrictions on the stock pledge activities in ultimately government-controlled firms. Any stock pledge conducted by the controlling shareholders in those SOEs should be under special supervision and monitoring from the local government or state-owned asset management department. Therefore, the controlling shareholder has fewer expropriation incentives in those

\footnotetext{
18 The estimated value of the targets are missing for nearly half of the sample because most targets are private firms.
} 
SOE firms with share pledging. We argue that share pledge induces more serious agency problems for non-SOEs than SOEs. Table 8 provides the regression results. The coefficient on the interaction term between SOE and Pledge_Dummy are positive and significant in both column (1) and (2), indicating a mitigating effect of SOE on the negative relationship between share pledge and announcement return.

Our second cross-sectional test examines whether the relationship between the stock pledge and CAR differs between firms with a high and low level of free cash flow. Prior research suggests that controlling shareholders are more likely to expropriate corporate resources through M\&A when firms have more free cash flows (e.g., Jensen, 1986; Lang et al., 1991; Harford, 1999). Therefore, we expect that the negative effect of share pledge on M\&A announcement return is more pronounced when the firm has a higher level of free cash flow. We rank firms by industry years using the ratio of free cash flow to total assets. FCF_High is a dummy that equals 1 if the firm is among the top 20\%, and 0 otherwise. As shown in column (4) of Table 8, high-level free cash flow pledging firms experience $2.2 \%$ more negative return during the $[-5,+5]$ event window. Although the coefficient on the interaction term in column (3) is not significant, it is negative with the $\mathrm{t}-\mathrm{value}$ of -1.46 .

\section{The long-term performance for the pledging acquirers}

The negative association between CAR and pledge indicates that investors predict worse future performance for the pledging firms due to their self-interested acquisition. In this section, we provide evidence on long-term performance in terms of post-acquisition ROA and goodwill impairment. 


\subsection{ROA}

We firstly test the industry adjusted ROA 1/2/3 year(s) after the M\&A announcement. It is ideal to use the deal completion date. However, the missing value problem is severe. In order not to lose too many observations, we follow Yang et al. (2019) and use the announcement date. Industry adjusted ROA is defined as the difference between the firm ROA and industry median. To control for pre-M\&A performance, we add adjusted ROA 1, 2, and 3 year(s) before the announcement in the regression.

As shown in Table 9, acquirers with their controlling shareholder stock pledge exhibit significantly worse accounting performance up to three years after the acquisition. This finding is in line with our previous results of lower announcement return, indicating that such takeovers are subjected to the expropriation for the controlling shareholder to extract private benefits. In addition, in an untabulated analyses, we find the results are robust if we use the change in ROA as an alternative dependent variable.

\subsection{Post M\&A goodwill impairment}

Our aggravated expropriation hypothesis predicts that pledging firms are more likely to engage in self-serving acquisitions due to the agency problem induced by the divergence of voting rights and cash-flow rights. In addition to the evidence on announcement returns and post-M\&A ROA, we further test our prediction with goodwill impairment to identify the quality of the acquisition in the long run. Goodwill impairment signals a disappointing outcome from the M\&A deal. We expect the pledging acquirers to be more likely to undergo goodwill impairment. We define Impairment_Dummy as a dummy variable that equals one if the firm confirms the goodwill impairment during three years after their M\&A announcements, and 0 otherwise. Since goodwill 
impairment data in CSMAR begins in 2007 and we require firms with enough data during 3 years of post-M\&A period, our sample only covers M\&A deals during 2006-2015 in this test. Using the probit model, the coefficient on Pledge_Dummy is positive and significant at $5 \%$ level, indicating that the acquirers fail to benefit from those takeovers as expected. As a result, the minority shareholders suffer from such acquisitions subjected to the controlling shareholder's tunneling behavior $^{19}$.

\section{Conclusion}

In this paper, we examine the effect of the controlling shareholder stock pledge on corporate acquisitions. We find that firms are more likely to conduct corporate acquisitions after the share pledge by their controlling shareholders which supports the aggravated expropriation hypothesis. Moreover, M\&A deals initiated by pledging firms obtain lower announcement returns. The negative relationship between the stock pledge and return is robust to the alternative variable definition, fixed effects, and sample selections. To mitigate the endogeneity concerns, we conduct the instrumental variable approach as well as the difference in differences tests utilizing a regulation change in 2013. We further examine the mechanisms driving the impediment effect from share pledge. We find that acquirers with the controlling shareholder pledging their shares tend to overpay in the deals and are more likely to be involved in related party transactions. Besides, the relationship between share pledge and returns is stronger for non-SOEs and the firm with highlevel free cash flow. Moreover, pledging firms have worse post-M\&A performance in terms of lower ROA and greater likelihood of goodwill impairment.

${ }^{19}$ Since the sample using the probit model drops significantly, we also conduct OLS regression for a robustness check. The results are consistent with Table 10. 
Overall, our findings suggest that, the controlling shareholders retain their decisive voting power on the corporate investment decisions after they pledge shares. Moreover, the stock pledge would even alter controlling shareholders' behavior to increasingly utilize corporate takeover for private benefits resulting in the expropriation on the minority shareholders. We shed light on the understanding of agency issues caused by share pledge due to the further deviation of voting and cash-flow rights. By documenting the causal effect of share pledge on bad M\&A decisions, our finding has significant policy implications regarding the minority share protection and the debate on the property of stock pledge. 


\section{References}

Agrawal, A. and Walkling, R.A., 1994. Executive careers and compensation surrounding takeover bids. The Journal of Finance, 49(3), pp.985-1014.

Amihud, Y. and Lev, B., 1981. Risk reduction as a managerial motive for conglomerate mergers. The Bell Journal of Economics, pp.605-617.

Anderson, R. and Puleo, M., 2020. Insider share-pledging and equity risk. Journal of Financial Services Research, pp.1-25.

Arouri, M., Gomes, M. and Pukthuanthong, K., 2019. Corporate social responsibility and M\&A uncertainty. Journal of Corporate Finance, 56, pp.176-198.

Bae, K.H., Kang, J.K. and Kim, J.M., 2002. Tunneling or value added? Evidence from mergers by Korean business groups. Journal of Finance, 57(6), pp.2695-2740.

Bebchuk, L.A., Kraakman, R. and Triantis, G., 2000. Stock pyramids, cross-ownership, and dual class equity: the mechanisms and agency costs of separating control from cash-flow rights. In Concentrated corporate ownership (pp. 295-318). University of Chicago Press.

Becht, M., Bolton, P. and Röell, A., 2003. Corporate governance and control. In Handbook of the Economics of Finance (Vol. 1, pp. 1-109). Elsevier.

Berkovitch, E. and Narayanan, M.P., 1993. Motives for takeovers: An empirical investigation. Journal of Financial and Quantitative Analysis, 28(3), pp.347-362.

Betton, S., Eckbo, B.E. and Thorburn, K.S., 2008. Corporate takeovers. In Handbook of Empirical Corporate Finance (pp. 291-429). Elsevier.

Bhaumik, S.K. and Selarka, E., 2012. Does ownership concentration improve M\&A outcomes in emerging markets?: Evidence from India. Journal of Corporate Finance, 18(4), pp.717-726.

Bi, X. and Wang, D., 2018. External sources of political connections: Financial advisors and Chinese acquisitions. International Journal of Finance \& Economics, 23(4), pp.705-722.

Bigelli, M. and Mengoli, S., 2004. Sub-optimal acquisition decisions under a majority shareholder system. Journal of Management and Governance, 8(4), pp.373-405.

f Thraya, C., 2008. Large shareholder entrenchment and performance: Empirical evidence from Canada. Journal of Business Finance \& Accounting, 35(1-2), pp.25-49.

Burkart, M. and Panunzi, F., 2006. Agency conflicts, ownership concentration, and legal shareholder protection. Journal of Financial Intermediation, 15(1), pp.1-31.

Chan, K., Chen, H.K., Hu, S.Y. and Liu, Y.J., 2018. Share pledges and margin call pressure. Journal of Corporate Finance, 52, pp.96-117.

Chen, A. and Kao, L., 2011. Effect of collateral characteristics on bank performance: Evidence from collateralized stocks in Taiwan. Journal of Banking \& Finance, 35(2), pp.300-309.

Chen, A., Kao, L. and Chen, Y.K., 2007. Agency costs of controlling shareholders' share collateral with Taiwan evidence. Review of Pacific Basin Financial Markets and Policies, 10(02), pp.173-191.

Chen, H.K. and Hu, S.Y., 2018. Insider Pledging: Its Information Content and Forced Sale. In: 2018 Financial Management Association Annual Meeting.

Cheung, Y.L., Rau, P.R. and Stouraitis, A., 2006. Tunneling, propping, and expropriation: evidence from connected party transactions in Hong Kong. Journal of Financial economics, 82(2), pp.343-386. 
Cheung, Y.L., Qi, Y., Rau, P.R. and Stouraitis, A., 2009. Buy high, sell low: How listed firms price asset transfers in related party transactions. Journal of Banking \& Finance, 33(5), pp.914-924.

Claessens, S., Djankov, S. and Lang, L.H., 2000. The separation of ownership and control in East Asian corporations. Journal of financial Economics, 58(1-2), pp.81-112.

Claessens, S., Djankov, S., Fan, J.P. and Lang, L.H., 2002. Disentangling the incentive and entrenchment effects of large shareholdings. Journal of Finance, 57(6), pp.2741-2771.

DeJong, D.V., Liao, K. and Xie, D., 2020. Controlling shareholder's share pledging and accounting manipulations. Available at SSRN 3274388.

Deutsch, Y., Keil, T. and Laamanen, T., 2007. Decision making in acquisitions: The effect of outside directors' compensation on acquisition patterns. Journal of Management, 33(1), pp.30-56.

Dou, Y., Masulis, R.W. and Zein, J., 2019. Shareholder wealth consequences of insider pledging of company stock as collateral for personal loans. Forthcoming, Review of Financial Studies.

Fama, E.F. and Jensen, M.C., 1983. Agency problems and residual claims. Journal of Law and Economics, 26(2), pp.327-349.

Fama, E.F. and Jensen, M.C., 1983. Separation of ownership and control. Journal of Law and Economics, 26(2), pp.301-325.

Grossman, S.J. and Hart, O.D., 1988. One share-one vote and the market for corporate control. Journal of Financial Economics, 20, pp.175-202.

Haleblian, J., Kim, J.Y. and Rajagopalan, N., 2006. The influence of acquisition experience and performance on acquisition behavior: Evidence from the US commercial banking industry. Academy of Management Journal, 49(2), pp.357-370.

Harford, J., 1999. Corporate cash reserves and acquisitions. Journal of Finance, 54(6), pp.1969-1997.

Harford, J., Humphery-Jenner, M. and Powell, R., 2012. The sources of value destruction in acquisitions by entrenched managers. Journal of Financial Economics, 106(2), pp.247-261.

Harris, M. and Raviv, A., 1988. Corporate governance: Voting rights and majority rules. Journal of Financial Economics, 20, pp.203-235.

Haunschild, P.R. and Beckman, C.M., 1998. When do interlocks matter?: Alternate sources of information and interlock influence. Administrative Science Quarterly, pp.815-844.

Haunschild, P.R., 1993. Interorganizational imitation: The impact of interlocks on corporate acquisition activity. Administrative Science Quarterly, pp.564-592.

Hayward, M.L. and Hambrick, D.C., 1997. Explaining the premiums paid for large acquisitions: Evidence of CEO hubris. Administrative Science Quarterly, pp.103-127.

Jensen, M.C. and Meckling, W.H., 1976. Theory of the firm: Managerial behavior, agency costs and ownership structure. Journal of Financial Economics, 3(4), pp.305-360.

Jensen, M.C., 1986. Agency costs of free cash flow, corporate finance, and takeovers. American Economic Review, 76(2), pp.323-329.

Johnson, S., La Porta, R., Lopez-de-Silanes, F. and Shleifer, A., 2000. Tunneling. American Economic Review, 90(2), pp.22-27.

La Porta, R., Lopez-de-Silanes, F. and Shleifer, A., 1999. Corporate ownership around the world. The Journal of Finance, 54(2), pp.471-517.

La Porta, R., Lopez-de-Silanes, F., Shleifer, A. and Vishny, R., 2000. Investor protection and corporate governance. Journal of Financial Economics, 58(1-2), pp.3-27. 
La Porta, R., Lopez-de-Silanes, F., Shleifer, A. and Vishny, R., 2002. Investor protection and corporate valuation. Journal of Finance, 57(3), pp.1147-1170.

La Porta, R., Lopez-de-Silanes, F., Shleifer, A. and Vishny, R.W., 2000. Agency problems and dividend policies around the world. Journal of Finance, 55(1), pp.1-33.

Lang, L.H., Stulz, R. and Walkling, R.A., 1991. A test of the free cash flow hypothesis: The case of bidder returns. Journal of Financial Economics, 29(2), pp.315-335.

Lewellen, W., Loderer, C. and Rosenfeld, A., 1985. Merger decisions and executive stock ownership in acquiring firms. Journal of Accounting and Economics, 7(1-3), pp.209-231.

Li, M., Liu, C. and Scott, T., 2019. Share pledges and firm value. Pacific-Basin Finance Journal, 55, pp.192-205.

Li, W., Zhou, J., Yan, Z. and Zhang, H., 2019. Controlling shareholder share pledging and firm cash dividends. Emerging Markets Review, p.100671.

Liu, Q., Luo, T. and Tian, G., 2016. Political connections with corrupt government bureaucrats and corporate M\&A decisions: A natural experiment from the anti-corruption cases in China. Pacific-Basin Finance Journal, 37, pp.5280 .

Malmendier, U. and Tate, G., 2008. Who makes acquisitions? CEO overconfidence and the market's reaction. Journal of Financial Economics, 89(1), pp.20-43.

Masulis, R.W., Wang, C. and Xie, F., 2007. Corporate governance and acquirer returns. Journal of Finance, 62(4), pp.1851-1889.

Meng, Q., Ni, X. and Zhang, J., 2019. Share pledging and corporate risk-taking: Insights from the Chinese stock market. Available at SSRN 3237881.

Moeller, S.B., Schlingemann, F.P. and Stulz, R.M., 2004. Firm size and the gains from acquisitions. Journal of Financial Economics, 73(2), pp.201-228.

Morck, R., Shleifer, A. and Vishny, R.W., 1988. Management ownership and market valuation: An empirical analysis. Journal of Financial Economics, 20, pp.293-315.

Morck, R., Shleifer, A. and Vishny, R.W., 1990. Do managerial objectives drive bad acquisitions?. Journal of Finance, 45(1), pp.31-48.

Morck, Randall, Daniel Wolfenzon, and Bernard Yeung. "Corporate governance, economic entrenchment, and growth." Journal of Economic Literature 43, no. 3 (2005): 655-720.

Myers, S.C. and Majluf, N.S., 1984. Corporate financing and investment decisions when firms have information that investors do not have. Journal of Financial Economics, 13(2), pp.187-221.

Ouyang, C., Xiong, J. and Fan, L., 2019. Do insiders share pledging affect executive pay-for-performance sensitivity?. International Review of Economics \& Finance, 63, pp.226-239.

Pang, C. and Wang, Y., 2020. Stock pledge, risk of losing control and corporate innovation. Journal of Corporate Finance, 60, p.101534.

Pang, C. and Wang, Y., 2020. Stock pledge, risk of losing control and corporate innovation. Journal of Corporate Finance, 60, p.101534.

Sanders, W.G., 2001. Behavioral responses of CEOs to stock ownership and stock option pay. Academy of Management Journal, 44(3), pp.477-492.

Shleifer, A. and Vishny, R.W., 1991. Takeovers in the'60s and the'80s: Evidence and Implications. Strategic Management Journal, 12(S2), pp.51-59.

Shleifer, A. and Vishny, R.W., 1997. A survey of corporate governance. Journal of Finance, 52(2), pp.737-783. 
Singh, P.P., 2018. The inside job: Share pledges by insiders and earnings management. Available at SSRN 3294165.

Stulz, R., 1988. Managerial control of voting rights: Financing policies and the market for corporate control. Journal of Financial Economics, 20, pp.25-54.

Stulz, R., 1990. Managerial discretion and optimal financing policies. Journal of Financial Economics, 26(1), pp.327.

Thraya, M.F., 2015. Are controlling shareholders extracting private benefits from European public acquisitions?. International Journal of Managerial Finance.

Thraya, M.F. and Hamza, T., 2019. Bidder excess control, target overpayment and control contestability: Evidence from France. The Quarterly Review of Economics and Finance, 72, pp.178-190.

Tirole, J., 1986. Hierarchies and bureaucracies: On the role of collusion in organizations. JL Econ. \& Org., 2, p.181.

Wang, Y.C. and Chou, R.K., 2018. The impact of share pledging regulations on stock trading and firm valuation. Journal of Banking \& Finance, 89, pp.1-13.

Westphal, J.D., Seidel, M.D.L. and Stewart, K.J., 2001. Second-order imitation: Uncovering latent effects of board network ties. Administrative Science Quarterly, 46(4), pp.717-747.

Yang, J., Guariglia, A. and Guo, J.M., 2019. To what extent does corporate liquidity affect M\&A decisions, method of payment and performance? Evidence from China. Journal of Corporate Finance, 54, pp.128-152.

Zhang, M., Gao, S., Guan, X. and Jiang, F., 2014. Controlling Shareholder-Manager Collusion and Tunneling: Evidence from C hina. Corporate Governance: An International Review, 22(6), pp.440-459.

Zhang, Junzi and Bilinski, Pawel and Raonic, Ivana, Does Regulatory Monitoring Improve M\&A Outcomes? Evidence from Chinese Comment Letters (November 4, 2019). Available at SSRN: https://ssrn.com/abstract=3352597 or http://dx.doi.org/10.2139/ssrn.3352597

Zhao, W., Zhang, W., Xiong, X. and Zou, G., 2019. Share pledges, tone of earnings communication conferences, and market reaction: evidence from China. Accounting \& Finance.

Zhou, B., Guo, J., Hua, J. and Doukas, A.J., 2015. Does state ownership drive M\&A performance? Evidence from China. European Financial Management, 21(1), pp.79-105.

Zingales, L., 1994. The value of the voting right: A study of the Milan stock exchange experience. The Review of Financial Studies, 7(1), pp.125-148. 
Table 1 Descriptive statistics

This table reports the descriptive statistics for the full sample as well as the subsample of acquires and non-acquires from 20032017. All the variables are winsorized at $1 \%$ and $99 \%$ levels. Detailed definition of all the variables are listed in Appendix A

\begin{tabular}{|c|c|c|c|c|c|c|c|c|c|}
\hline \multirow[b]{2}{*}{ Variable } & \multicolumn{3}{|c|}{ Acquirer (6553) } & \multicolumn{3}{|c|}{ Non-Acquirer (19207) } & \multicolumn{3}{|c|}{ All (25760) } \\
\hline & Mean & SD & Median & Mean & SD & Median & Mean & SD & Median \\
\hline M\&A & 1.000 & 0.000 & 1.000 & 0.000 & 0.000 & 0.000 & 0.254 & 0.435 & 0.000 \\
\hline Pledge_Dummy & 0.371 & 0.483 & 0.000 & 0.305 & 0.460 & 0.000 & 0.322 & 0.467 & 0.000 \\
\hline Size & 21.788 & 1.237 & 21.648 & 21.763 & 1.279 & 21.608 & 21.770 & 1.268 & 21.620 \\
\hline Annual Return & 0.396 & 0.926 & 0.104 & 0.293 & 0.864 & 0.026 & 0.319 & 0.881 & 0.043 \\
\hline Cash & 0.195 & 0.150 & 0.152 & 0.184 & 0.145 & 0.142 & 0.186 & 0.146 & 0.145 \\
\hline ROA & 0.039 & 0.058 & 0.038 & 0.032 & 0.065 & 0.034 & 0.034 & 0.063 & 0.035 \\
\hline Intangible & 0.044 & 0.051 & 0.030 & 0.045 & 0.053 & 0.031 & 0.045 & 0.053 & 0.030 \\
\hline Leverage & 0.441 & 0.218 & 0.439 & 0.457 & 0.223 & 0.453 & 0.453 & 0.222 & 0.449 \\
\hline Capital Expenditure & 0.054 & 0.052 & 0.039 & 0.055 & 0.054 & 0.038 & 0.055 & 0.054 & 0.038 \\
\hline Tobin's Q & 2.744 & 2.067 & 2.075 & 2.605 & 2.017 & 1.932 & 2.640 & 2.030 & 1.969 \\
\hline Blockholders & 0.357 & 0.151 & 0.338 & 0.365 & 0.156 & 0.342 & 0.363 & 0.155 & 0.341 \\
\hline Board Size & 8.829 & 1.808 & 9.000 & 8.975 & 1.853 & 9.000 & 8.938 & 1.843 & 9.000 \\
\hline Board Independent & 0.368 & 0.053 & 0.333 & 0.365 & 0.052 & 0.333 & 0.366 & 0.053 & 0.333 \\
\hline SOE & 0.416 & 0.493 & 0.000 & 0.499 & 0.500 & 0.000 & 0.478 & 0.499 & 0.000 \\
\hline CEO Duality & 0.232 & 0.422 & 0.000 & 0.205 & 0.404 & 0.000 & 0.212 & 0.409 & 0.000 \\
\hline Cash Payment & 0.839 & 0.368 & 1.000 & & & & & & \\
\hline Cash Mixed & 0.082 & 0.275 & 0.000 & & & & & & \\
\hline Premium & 0.489 & 2.682 & 0.000 & & & & & & \\
\hline CAR $[-3,+3]$ & 0.020 & 0.128 & 0.002 & & & & & & \\
\hline CAR $[-5,+5]$ & 0.022 & 0.152 & 0.002 & & & & & & \\
\hline Related & 0.379 & 0.485 & 0.000 & & & & & & \\
\hline Significant & 0.115 & 0.319 & 0.000 & & & & & & \\
\hline Relative Size & 0.239 & 0.770 & 0.028 & & & & & & \\
\hline Runup_stock & 0.230 & 0.672 & 0.040 & & & & & & \\
\hline Complete & 0.935 & 0.247 & 1.000 & & & & & & \\
\hline
\end{tabular}


Table 2 Stock pledge and M\&A tendency

This table reports the regression results of M\&A tendency on stock pledge based on the Probit model. M\&A is a dummy that equals one if the firm announces a merger and acquisition, and zero otherwise. Pledge_Dummy is a dummy that equals one if the controlling shareholder of the firm has shares pledged at the end of the year, and zero otherwise. The definition of other controls are listed in Appendix A. The regression includes industry, year and province fixed effects. The t-statistics in parentheses are based on standard errors adjusted for firm-level clustering. $* * *, * * *$ represent statistical significance at the $1 \%, 5 \%$ and $10 \%$ levels, respectively.

$\operatorname{Prob}(\mathrm{M} \& \mathrm{~A})$

Pledge_Dummy

Size

Annual Return

$0.132 * * *$

$0.028 * *$

(2.40)

$0.034 * *$

Cash

$0.172 * *$

ROA

$0.796 * * *$

Intangible

$-0.265$

Leverage

$-0.055$

$(-0.97)$

Capital Expenditure $-0.096$

Tobin's Q

Blockholders

$-0.084$

(-1.22)

Board Size

$-0.012 *$

Board Independent

$-0.030$

$(-0.15)$

SOE

$-0.128 * * *$

$(-5.05)$

CEO Duality

0.008

(0.34)

Industry FEs

Year FEs

$\mathrm{Y}$

Y

Province FEs

Y

Observations

25,757

Pseudo R-squared 
Table 3 Stock pledge and M\&A announcement returns

This table reports the OLS regression results of M\&A announcement returns. CAR $[-3,+3]($ CAR $[-5,+5])$ is the cumulative abnormal returns in the 7-day $[-3,+3](11-$ day $[-5,+5])$ event window using the market model with parameters estimated over the 200 trading days ending 61 days prior to the deal announcement date. Pledge_Dummy is a dummy that equals one if the controlling shareholder of the firm has shares pledged at the end of the year, and zero otherwise. The definition of other controls are listed in Appendix A. The regressions include industry, year and province fixed effects. The t-statistics in parentheses are based on standard errors adjusted for firm-level clustering. $* * *, * * *$ represent statistical significance at the $1 \%, 5 \%$ and $10 \%$ levels, respectively.

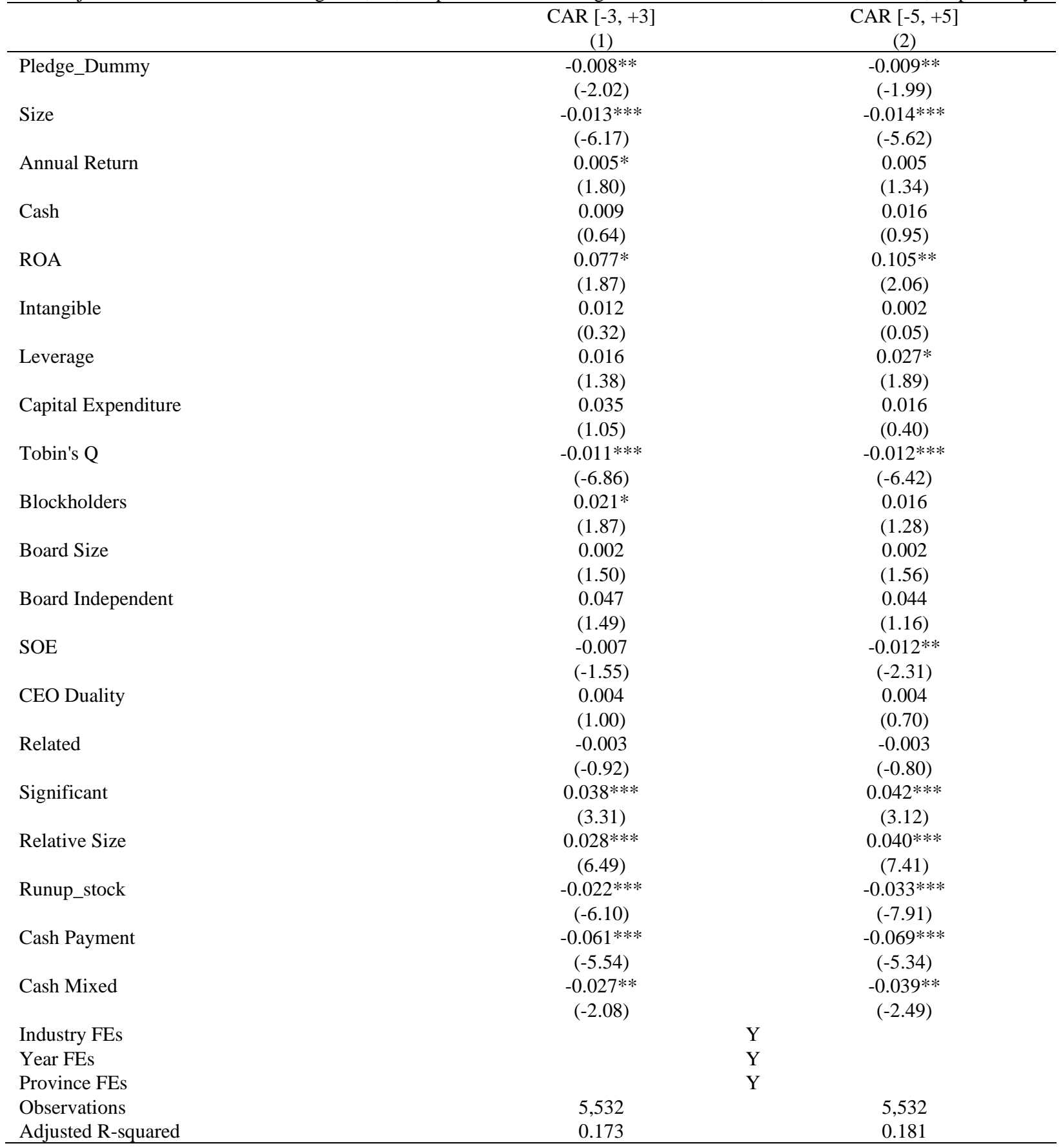


Table 4 Robustness tests

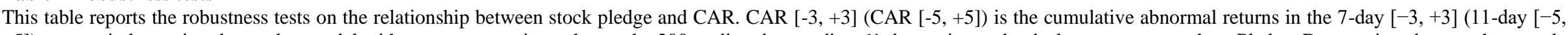

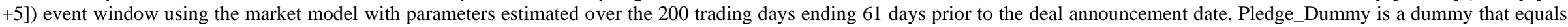

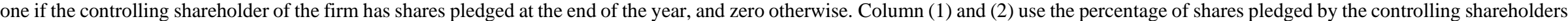

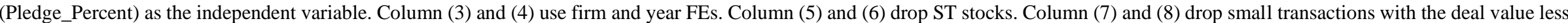

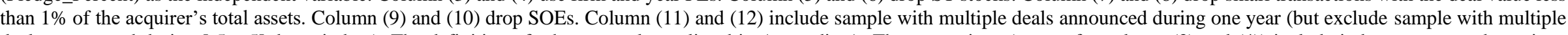

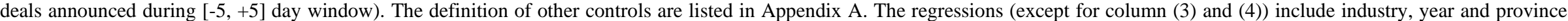

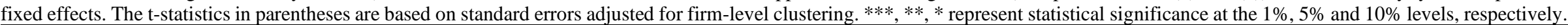

\begin{tabular}{|c|c|c|c|c|c|c|c|c|c|c|c|c|}
\hline & \multicolumn{2}{|c|}{ Pledge Percent } & \multicolumn{2}{|c|}{ Firm and Year FEs } & \multicolumn{2}{|c|}{ Drop ST Stocks } & \multicolumn{2}{|c|}{ Drop Small Deals } & \multicolumn{2}{|c|}{ Drop SOEs } & \multicolumn{2}{|c|}{ Expanded Sample } \\
\hline & $\begin{array}{c}\text { CAR }[-3,+3] \\
(1)\end{array}$ & $\begin{array}{c}\text { CAR }[-5,+5] \\
(2)\end{array}$ & $\begin{array}{c}\text { CAR }[-3,+3] \\
(3)\end{array}$ & $\begin{array}{c}\text { CAR }[-5,+5] \\
(4)\end{array}$ & $\begin{array}{c}\text { CAR }[-3,+3] \\
(5)\end{array}$ & $\begin{array}{c}\text { CAR }[-5,+5] \\
(6)\end{array}$ & $\begin{array}{c}\text { CAR }[-3,+3] \\
(7)\end{array}$ & $\begin{array}{c}\text { CAR }[-5,+5] \\
(8)\end{array}$ & $\begin{array}{c}\text { CAR }[-3,+3] \\
(9)\end{array}$ & $\begin{array}{c}\text { CAR }[-5,+5] \\
(10)\end{array}$ & $\begin{array}{c}\text { CAR }[-3,+3] \\
(11)\end{array}$ & $\begin{array}{c}\text { CAR }[-5,+5] \\
(12)\end{array}$ \\
\hline Pledge_Dummy & & & $\begin{array}{c}-0.013 * * \\
(-2.24)\end{array}$ & $\begin{array}{c}-0.014 * \\
(-1.91)\end{array}$ & $\begin{array}{c}-0.009 * * \\
(-2.31)\end{array}$ & $\begin{array}{c}-0.010 * * \\
(-2.24)\end{array}$ & $\begin{array}{c}-0.010 * \\
(-1.92)\end{array}$ & $\begin{array}{c}-0.012 * * \\
(-1.98)\end{array}$ & $\begin{array}{c}-0.012 * * \\
(-2.41)\end{array}$ & $\begin{array}{c}-0.014 * * \\
(-2.34)\end{array}$ & $\begin{array}{c}-0.005^{*} \\
(-1.70)\end{array}$ & $\begin{array}{c}-0.007 * * \\
(-2.12)\end{array}$ \\
\hline Pledge_Percent & $\begin{array}{c}-0.015^{* * *} \\
(-2.63)\end{array}$ & $\begin{array}{c}-0.017 * * \\
(-2.37)\end{array}$ & & & & & & & & & & \\
\hline Size & $\begin{array}{c}-0.013 * * * \\
(-6.17)\end{array}$ & $\begin{array}{c}-0.014 * * * \\
(-5.62)\end{array}$ & $\begin{array}{c}-0.029 * * * \\
(-5.56)\end{array}$ & $\begin{array}{c}-0.034 * * * \\
(-5.35)\end{array}$ & $\begin{array}{c}-0.012 * * * \\
(-5.61)\end{array}$ & $\begin{array}{c}-0.012 * * * \\
(-5.18)\end{array}$ & $\begin{array}{c}-0.017 * * * \\
(-5.71)\end{array}$ & $\begin{array}{c}-0.019 * * * \\
(-5.46)\end{array}$ & $\begin{array}{c}-0.017 * * * \\
(-5.60)\end{array}$ & $\begin{array}{c}-0.019 * * * \\
(-5.07)\end{array}$ & $\begin{array}{c}-0.011 * * * \\
(-7.51)\end{array}$ & $\begin{array}{c}-0.012 * * * \\
(-7.09)\end{array}$ \\
\hline Annual Return & $\begin{array}{c}0.005^{*} \\
(1.76)\end{array}$ & $\begin{array}{l}0.005 \\
(1.31)\end{array}$ & $\begin{array}{l}-0.001 \\
(-0.11)\end{array}$ & $\begin{array}{l}-0.003 \\
(-0.49)\end{array}$ & $\begin{array}{c}0.008 * * \\
(2.47)\end{array}$ & $\begin{array}{c}0.008 * * \\
(2.10)\end{array}$ & $\begin{array}{l}0.006 \\
(1.64)\end{array}$ & $\begin{array}{l}0.006 \\
(1.29)\end{array}$ & $\begin{array}{c}0.008 * * \\
(2.03)\end{array}$ & $\begin{array}{l}0.008^{*} \\
(1.83)\end{array}$ & $\begin{array}{c}0.005^{* *} \\
(2.34)\end{array}$ & $\begin{array}{c}0.004 * \\
(1.76)\end{array}$ \\
\hline Cash & $\begin{array}{l}0.009 \\
(0.62)\end{array}$ & $\begin{array}{l}0.016 \\
(0.95)\end{array}$ & $\begin{array}{l}0.027 \\
(1.15)\end{array}$ & $\begin{array}{l}0.039 \\
(1.44)\end{array}$ & $\begin{array}{l}0.008 \\
(0.55)\end{array}$ & $\begin{array}{l}0.016 \\
(0.89)\end{array}$ & $\begin{array}{l}0.008 \\
(0.41)\end{array}$ & $\begin{array}{l}0.014 \\
(0.64)\end{array}$ & $\begin{array}{l}0.001 \\
(0.07)\end{array}$ & $\begin{array}{l}0.007 \\
(0.30)\end{array}$ & $\begin{array}{l}0.006 \\
(0.50)\end{array}$ & $\begin{array}{l}0.008 \\
(0.63)\end{array}$ \\
\hline ROA & $\begin{array}{c}0.073 * \\
(1.77)\end{array}$ & $\begin{array}{c}0.101 * * \\
(1.97)\end{array}$ & $\begin{array}{c}0.099 * \\
(1.74)\end{array}$ & $\begin{array}{c}0.143^{* *} \\
(1.98)\end{array}$ & $\begin{array}{l}0.062 \\
(1.39)\end{array}$ & $\begin{array}{l}0.084 \\
(1.54)\end{array}$ & $\begin{array}{c}0.100 * * \\
(1.97)\end{array}$ & $\begin{array}{c}0.140 * * \\
(2.21)\end{array}$ & $\begin{array}{c}0.148 * * * \\
(2.61)\end{array}$ & $\begin{array}{c}0.201 * * * \\
(2.81)\end{array}$ & $\begin{array}{l}0.040 \\
(1.18)\end{array}$ & $\begin{array}{c}0.072 * \\
(1.77)\end{array}$ \\
\hline Intangible & $\begin{array}{l}0.013 \\
(0.33)\end{array}$ & $\begin{array}{l}0.003 \\
(0.07)\end{array}$ & $\begin{array}{l}0.080 \\
(1.23)\end{array}$ & $\begin{array}{c}0.142 * \\
(1.76)\end{array}$ & $\begin{array}{l}-0.003 \\
(-0.09)\end{array}$ & $\begin{array}{l}-0.015 \\
(-0.33)\end{array}$ & $\begin{array}{l}0.002 \\
(0.03)\end{array}$ & $\begin{array}{l}-0.019 \\
(-0.31)\end{array}$ & $\begin{array}{l}0.068 \\
(1.11)\end{array}$ & $\begin{array}{l}0.050 \\
(0.63)\end{array}$ & $\begin{array}{l}-0.004 \\
(-0.13)\end{array}$ & $\begin{array}{l}-0.008 \\
(-0.23)\end{array}$ \\
\hline Leverage & $\begin{array}{l}0.018 \\
(1.51)\end{array}$ & $\begin{array}{c}0.029 * * \\
(2.00)\end{array}$ & $\begin{array}{c}0.053 * * * \\
(2.59)\end{array}$ & $\begin{array}{c}0.064 * * \\
(2.51)\end{array}$ & $\begin{array}{l}0.006 \\
(0.46)\end{array}$ & $\begin{array}{l}0.013 \\
(0.91)\end{array}$ & $\begin{array}{l}0.019 \\
(1.27)\end{array}$ & $\begin{array}{c}0.037 * * \\
(2.04)\end{array}$ & $\begin{array}{l}0.020 \\
(1.14)\end{array}$ & $\begin{array}{l}0.035 \\
(1.62)\end{array}$ & $\begin{array}{l}0.002 \\
(0.20)\end{array}$ & $\begin{array}{l}0.011 \\
(0.97)\end{array}$ \\
\hline $\begin{array}{l}\text { Capital } \\
\text { Expenditure }\end{array}$ & $\begin{array}{l}0.033 \\
(1.00)\end{array}$ & $\begin{array}{l}0.014 \\
(0.36)\end{array}$ & $\begin{array}{l}0.020 \\
(0.40)\end{array}$ & $\begin{array}{l}0.015 \\
(0.24)\end{array}$ & $\begin{array}{l}0.034 \\
(1.03)\end{array}$ & $\begin{array}{l}0.013 \\
(0.35)\end{array}$ & $\begin{array}{l}0.047 \\
(1.08)\end{array}$ & $\begin{array}{l}0.033 \\
(0.65)\end{array}$ & $\begin{array}{l}0.045 \\
(0.89)\end{array}$ & $\begin{array}{l}0.006 \\
(0.10)\end{array}$ & $\begin{array}{l}0.026 \\
(1.05)\end{array}$ & $\begin{array}{l}0.018 \\
(0.64)\end{array}$ \\
\hline Tobin's Q & $\begin{array}{c}-0.011^{* * *} \\
(-6.90)\end{array}$ & $\begin{array}{c}-0.012 * * * \\
(-6.46)\end{array}$ & $\begin{array}{c}-0.015 * * * \\
(-6.21)\end{array}$ & $\begin{array}{c}-0.015^{* * *} \\
(-5.18)\end{array}$ & $\begin{array}{c}-0.012 * * * \\
(-6.88)\end{array}$ & $\begin{array}{c}-0.013 * * * \\
(-6.42)\end{array}$ & $\begin{array}{c}-0.012 * * * \\
(-6.91)\end{array}$ & $\begin{array}{c}-0.014 * * * \\
(-6.56)\end{array}$ & $\begin{array}{c}-0.013^{* * *} \\
(-6.63)\end{array}$ & $\begin{array}{c}-0.014 * * * \\
(-6.29)\end{array}$ & $\begin{array}{c}-0.009 * * * \\
(-8.90)\end{array}$ & $\begin{array}{c}-0.011 * * * \\
(-8.62)\end{array}$ \\
\hline Blockholders & $\begin{array}{c}0.019 * \\
(1.72)\end{array}$ & $\begin{array}{l}0.014 \\
(1.13)\end{array}$ & $\begin{array}{l}0.024 \\
(0.77)\end{array}$ & $\begin{array}{l}0.054 \\
(1.42)\end{array}$ & $\begin{array}{c}0.019 * \\
(1.70)\end{array}$ & $\begin{array}{l}0.014 \\
(1.09)\end{array}$ & $\begin{array}{l}0.023 \\
(1.56)\end{array}$ & $\begin{array}{l}0.021 \\
(1.26)\end{array}$ & $\begin{array}{c}0.028^{*} \\
(1.76)\end{array}$ & $\begin{array}{l}0.019 \\
(1.02)\end{array}$ & $\begin{array}{l}0.009 \\
(1.04)\end{array}$ & $\begin{array}{l}0.003 \\
(0.34)\end{array}$ \\
\hline
\end{tabular}




\begin{tabular}{|c|c|c|c|c|c|c|c|c|c|c|c|c|}
\hline Board Size & $\begin{array}{l}0.001 \\
(1.46)\end{array}$ & $\begin{array}{l}0.002 \\
(1.51)\end{array}$ & $\begin{array}{l}0.002 \\
(0.71)\end{array}$ & $\begin{array}{l}0.002 \\
(0.82)\end{array}$ & $\begin{array}{c}0.002 * \\
(1.68)\end{array}$ & $\begin{array}{l}0.002 \\
(1.61)\end{array}$ & $\begin{array}{c}0.002 * \\
(1.74)\end{array}$ & $\begin{array}{c}0.003 * * \\
(2.15)\end{array}$ & $\begin{array}{c}0.003 * \\
(1.85)\end{array}$ & $\begin{array}{l}0.003 \\
(1.30)\end{array}$ & $\begin{array}{l}0.001 * \\
(1.93)\end{array}$ & $\begin{array}{c}0.002 * * \\
(2.17)\end{array}$ \\
\hline Board Independent & $\begin{array}{l}0.047 \\
(1.49)\end{array}$ & $\begin{array}{l}0.043 \\
(1.15)\end{array}$ & $\begin{array}{l}0.066 \\
(1.15)\end{array}$ & $\begin{array}{l}0.058 \\
(0.85)\end{array}$ & $\begin{array}{c}0.055^{*} \\
(1.73)\end{array}$ & $\begin{array}{l}0.058 \\
(1.52)\end{array}$ & $\begin{array}{l}0.067 \\
(1.55)\end{array}$ & $\begin{array}{l}0.067 \\
(1.32)\end{array}$ & $\begin{array}{l}0.048 \\
(1.00)\end{array}$ & $\begin{array}{l}0.053 \\
(0.90)\end{array}$ & $\begin{array}{l}0.028 \\
(1.06)\end{array}$ & $\begin{array}{l}0.021 \\
(0.70)\end{array}$ \\
\hline SOE & $\begin{array}{c}-0.008^{*} \\
(-1.88)\end{array}$ & $\begin{array}{c}-0.013 * * \\
(-2.57)\end{array}$ & $\begin{array}{c}-0.025 * * \\
(-2.09)\end{array}$ & $\begin{array}{c}-0.030 * * \\
(-2.03)\end{array}$ & $\begin{array}{l}-0.005 \\
(-1.18)\end{array}$ & $\begin{array}{c}-0.008^{*} \\
(-1.70)\end{array}$ & $\begin{array}{c}-0.010^{*} \\
(-1.70)\end{array}$ & $\begin{array}{c}-0.018^{* *} \\
(-2.52)\end{array}$ & & & $\begin{array}{l}-0.004 \\
(-1.34)\end{array}$ & $\begin{array}{c}-0.009 * * \\
(-2.37)\end{array}$ \\
\hline CEO Duality & $\begin{array}{l}0.004 \\
(0.97)\end{array}$ & $\begin{array}{l}0.003 \\
(0.67)\end{array}$ & $\begin{array}{c}0.019 * * \\
(2.41)\end{array}$ & $\begin{array}{c}0.022^{* *} \\
(2.21)\end{array}$ & $\begin{array}{l}0.005 \\
(1.10)\end{array}$ & $\begin{array}{l}0.005 \\
(0.87)\end{array}$ & $\begin{array}{l}0.005 \\
(0.94)\end{array}$ & $\begin{array}{l}0.004 \\
(0.64)\end{array}$ & $\begin{array}{l}0.004 \\
(0.70)\end{array}$ & $\begin{array}{l}0.003 \\
(0.53)\end{array}$ & $\begin{array}{l}-0.001 \\
(-0.21)\end{array}$ & $\begin{array}{l}-0.002 \\
(-0.46)\end{array}$ \\
\hline Related & $\begin{array}{l}-0.003 \\
(-0.88)\end{array}$ & $\begin{array}{l}-0.003 \\
(-0.77)\end{array}$ & $\begin{array}{l}-0.002 \\
(-0.51)\end{array}$ & $\begin{array}{l}-0.001 \\
(-0.15)\end{array}$ & $\begin{array}{l}-0.002 \\
(-0.62)\end{array}$ & $\begin{array}{l}-0.002 \\
(-0.59)\end{array}$ & $\begin{array}{l}-0.004 \\
(-0.72)\end{array}$ & $\begin{array}{l}-0.004 \\
(-0.75)\end{array}$ & $\begin{array}{l}-0.002 \\
(-0.27)\end{array}$ & $\begin{array}{l}-0.003 \\
(-0.42)\end{array}$ & $\begin{array}{l}-0.001 \\
(-0.25)\end{array}$ & $\begin{array}{l}-0.001 \\
(-0.20)\end{array}$ \\
\hline Significant & $\begin{array}{c}0.039 * * * \\
(3.36)\end{array}$ & $\begin{array}{c}0.042 * * * \\
(3.16)\end{array}$ & $\begin{array}{c}0.066^{* * * *} \\
(4.69)\end{array}$ & $\begin{array}{c}0.076^{* * * *} \\
(4.58)\end{array}$ & $\begin{array}{c}0.033 * * * \\
(2.72)\end{array}$ & $\begin{array}{c}0.037 * * * \\
(2.68)\end{array}$ & $\begin{array}{c}0.038 * * * \\
(3.27)\end{array}$ & $\begin{array}{c}0.042 * * * \\
(3.09)\end{array}$ & $\begin{array}{c}0.031 * * \\
(2.18)\end{array}$ & $\begin{array}{l}0.031 * \\
(1.81)\end{array}$ & $\begin{array}{c}0.020 * * \\
(2.21)\end{array}$ & $\begin{array}{c}0.018^{*} \\
(1.72)\end{array}$ \\
\hline Relative Size & $\begin{array}{c}0.028 * * * \\
(6.50)\end{array}$ & $\begin{array}{c}0.040 * * * \\
(7.42)\end{array}$ & $\begin{array}{c}0.025^{* * * *} \\
(4.62)\end{array}$ & $\begin{array}{c}0.035^{* * *} \\
(5.32)\end{array}$ & $\begin{array}{c}0.041 * * * \\
(6.61)\end{array}$ & $\begin{array}{c}0.053 * * * \\
(6.94)\end{array}$ & $\begin{array}{c}0.027 * * * \\
(6.14)\end{array}$ & $\begin{array}{c}0.038 * * * \\
(7.09)\end{array}$ & $\begin{array}{c}0.035^{* * *} \\
(7.06)\end{array}$ & $\begin{array}{c}0.048 * * * \\
(7.66)\end{array}$ & $\begin{array}{c}0.045^{* * *} \\
(9.09)\end{array}$ & $\begin{array}{c}0.062 * * * \\
(10.18)\end{array}$ \\
\hline Runup_stock & $\begin{array}{c}-0.022 * * * \\
(-6.05)\end{array}$ & $\begin{array}{c}-0.033 * * * \\
(-7.87)\end{array}$ & $\begin{array}{c}-0.018 * * * \\
(-3.91)\end{array}$ & $\begin{array}{c}-0.029 * * * \\
(-5.39)\end{array}$ & $\begin{array}{c}-0.022 * * * \\
(-6.25)\end{array}$ & $\begin{array}{c}-0.033 * * * \\
(-8.02)\end{array}$ & $\begin{array}{c}-0.028 * * * \\
(-6.04)\end{array}$ & $\begin{array}{c}-0.040 * * * \\
(-7.42)\end{array}$ & $\begin{array}{c}-0.025 * * * \\
(-5.40)\end{array}$ & $\begin{array}{c}-0.037 * * * \\
(-6.57)\end{array}$ & $\begin{array}{c}-0.019 * * * \\
(-7.99)\end{array}$ & $\begin{array}{c}-0.029 * * * \\
(-10.20)\end{array}$ \\
\hline Cash Payment & $\begin{array}{c}-0.060 * * * \\
(-5.51)\end{array}$ & $\begin{array}{c}-0.068 * * * \\
(-5.31)\end{array}$ & $\begin{array}{c}-0.058 * * * \\
(-4.32)\end{array}$ & $\begin{array}{c}-0.066^{* * * *} \\
(-4.11)\end{array}$ & $\begin{array}{c}-0.050 * * * \\
(-4.44)\end{array}$ & $\begin{array}{c}-0.055^{* * *} \\
(-4.21)\end{array}$ & $\begin{array}{c}-0.065 * * * \\
(-5.71)\end{array}$ & $\begin{array}{c}-0.073 * * * \\
(-5.47)\end{array}$ & $\begin{array}{c}-0.058 * * * \\
(-3.80)\end{array}$ & $\begin{array}{c}-0.076^{* * *} \\
(-4.05)\end{array}$ & $\begin{array}{c}-0.047 * * * \\
(-5.22)\end{array}$ & $\begin{array}{c}-0.057 * * * \\
(-5.47)\end{array}$ \\
\hline Cash Mixed & $\begin{array}{c}-0.027 * * \\
(-2.06)\end{array}$ & $\begin{array}{c}-0.038 * * \\
(-2.47)\end{array}$ & $\begin{array}{c}-0.037 * * \\
(-2.42)\end{array}$ & $\begin{array}{c}-0.052 * * * \\
(-2.81)\end{array}$ & $\begin{array}{l}-0.018 \\
(-1.32)\end{array}$ & $\begin{array}{c}-0.027^{*} \\
(-1.69)\end{array}$ & $\begin{array}{c}-0.032 * * \\
(-2.44)\end{array}$ & $\begin{array}{c}-0.043 * * * \\
(-2.71)\end{array}$ & $\begin{array}{l}-0.022 \\
(-1.29)\end{array}$ & $\begin{array}{c}-0.038^{*} \\
(-1.83)\end{array}$ & $\begin{array}{c}-0.019 * \\
(-1.81)\end{array}$ & $\begin{array}{c}-0.030 * * \\
(-2.34)\end{array}$ \\
\hline Industry FEs & & & & & & & & $\mathrm{Y}$ & & & & \\
\hline Year FEs & & & $\mathrm{Y}$ & & & & & $\mathrm{Y}$ & & & & \\
\hline Province FEs & & & & & & & & $\mathrm{Y}$ & & & & \\
\hline Firm FEs & & & $\mathrm{Y}$ & & & & & & & & & \\
\hline Observations & 5,532 & 5,532 & 4,655 & 4,655 & 5,273 & 5,273 & 3,822 & 3,822 & 3,213 & 3,213 & 10,392 & 10,392 \\
\hline Adjusted R-squared & 0.173 & 0.182 & 0.213 & 0.218 & 0.170 & 0.172 & 0.197 & 0.209 & 0.203 & 0.215 & 0.140 & 0.153 \\
\hline
\end{tabular}


Table 5 Difference in differences approach

This table reports results using the difference in differences approach. The sample covers the year 2011-2012 and 2014-2015. 2013 is the event year. The treatment group includes firms whose controlling shareholders do not pledge shares in 2011 and 2012 , but pledge shares in 2014 and 2015. The control group includes firms whose controlling shareholders do not pledge shares during 2011-2015 and have the closest propensity score with the treatment firms. CAR $[-3,+3]($ CAR $[-5,+5])$ is the cumulative abnormal returns in the 7-day $[-3,+3](11$-day $[-5,+5])$ event window using the market model with parameters estimated over the 200 trading days ending 61 days prior to the deal announcement date. Treat is a dummy variable that equals 1 if the firm belongs to the treatment group, and 0 otherwise. Post is a dummy variable that equals 1 if the observation is after 2013, and 0 otherwise. The definition of other controls are listed in Appendix A. The regressions include industry, year and province fixed effects. The tstatistics in parentheses are based on standard errors adjusted for firm-level clustering. ***, **, * represent statistical significance at the $1 \%, 5 \%$ and $10 \%$ levels, respectively.

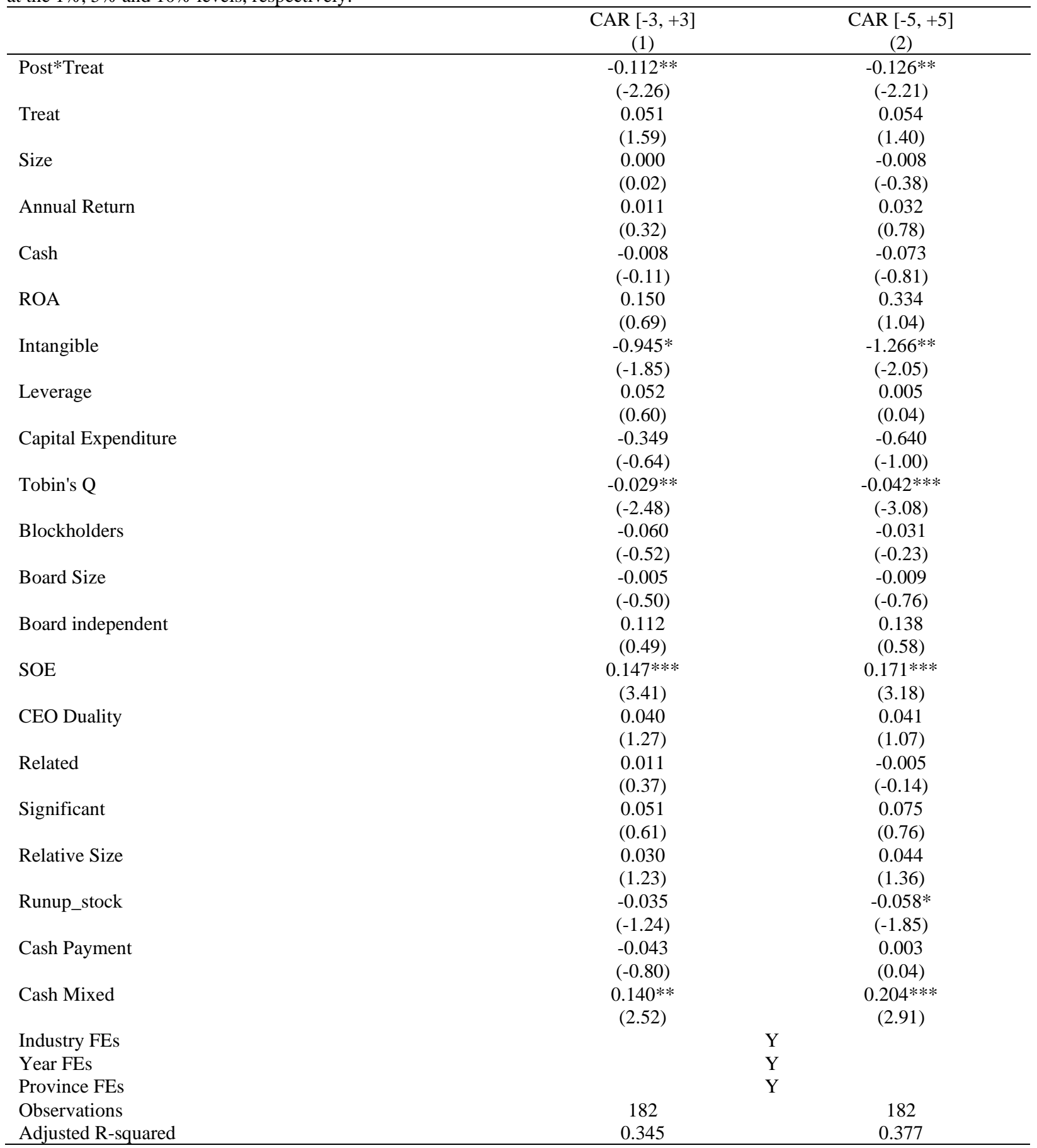


Table 6 Instrumental variable approach

This table reports the results using the instrumental variable approach. CAR $[-3,+3]($ CAR $[-5,+5])$ is the cumulative abnormal returns in the 7 -day $[-3,+3](11$-day $[-5,+5])$ event window using the market model with parameters estimated over the 200 trading days ending 61 days prior to the deal announcement date. Pledge_Percent equals the percentage of shares pledged by the controlling shareholders at the year-end. Pledge Percent (Peer) is the instrumental variable. In column (1)-(3), Pledge Percent (Peer) is defined as the average percent of shares pledged by the controlling shareholders from the peer companies operating in the same industry and located in the same province. In column (4)-(6), peers with M\&A activities during the $[-1,+1]$ year window are excluded when calculating the instrument. Pledge_Percent (Predicted) is the fitted value of Pledge_Percent. Column (1) and (4) report the first stage regressions. Column (2) \& (3) and (5) \& (6) report the second stage. The definition of other controls are listed in Appendix A. The regressions include industry, year and province fixed effects. The t-statistics in parentheses are based on standard errors adjusted for firm-level clustering. ***,**,* represent statistical significance at the $1 \%$, $5 \%$ and $10 \%$ levels, respectively.

\begin{tabular}{|c|c|c|c|c|c|c|}
\hline & \multicolumn{3}{|c|}{ Full sample } & \multicolumn{3}{|c|}{ Excluding peer with M\&A during $[-1,1]$ year window } \\
\hline & First-stage regression & Second-s & egressions & First-stage regression & Second-stag & sions \\
\hline & $\begin{array}{c}\text { Pledge (Percent) } \\
(1)\end{array}$ & $\begin{array}{c}\text { CAR }[-3,+3] \\
(2)\end{array}$ & $\begin{array}{c}\text { CAR }[-5,+5] \\
(3)\end{array}$ & $\begin{array}{c}\text { Pledge (Percent) } \\
(4)\end{array}$ & $\begin{array}{c}\text { CAR }[-3,+3] \\
(5) \\
\end{array}$ & $\begin{array}{c}\text { CAR }[-5,+5] \\
(6) \\
\end{array}$ \\
\hline Pledge_Percent (Predicted) & & $\begin{array}{c}-0.030 * * \\
(-2.06)\end{array}$ & $\begin{array}{c}-0.035 * * \\
(-2.02)\end{array}$ & & $\begin{array}{c}-0.059 * * * \\
(-2.77)\end{array}$ & $\begin{array}{c}-0.059 * * \\
(-2.34)\end{array}$ \\
\hline Pledge_Percent (Peer) & $\begin{array}{c}0.902 * * * \\
(36.40)\end{array}$ & & & $\begin{array}{c}0.612 * * * \\
(26.27)\end{array}$ & & \\
\hline Size & $\begin{array}{l}0.002 \\
(0.38)\end{array}$ & $\begin{array}{c}-0.013 * * * \\
(-5.44)\end{array}$ & $\begin{array}{c}-0.015^{* * * *} \\
(-5.22)\end{array}$ & $\begin{array}{l}0.004 \\
(0.84)\end{array}$ & $\begin{array}{c}-0.011 * * * \\
(-4.02)\end{array}$ & $\begin{array}{c}-0.012 * * * \\
(-3.86)\end{array}$ \\
\hline Annual Return & $\begin{array}{c}-0.025^{* * * *} \\
(-8.20)\end{array}$ & $\begin{array}{l}0.006 \\
(1.61)\end{array}$ & $\begin{array}{l}0.006 \\
(1.44)\end{array}$ & $\begin{array}{c}-0.031 * * * \\
(-9.11)\end{array}$ & $\begin{array}{l}0.008 * \\
(1.95)\end{array}$ & $\begin{array}{l}0.009 * \\
(1.92)\end{array}$ \\
\hline Cash & $\begin{array}{c}-0.175^{* * *} \\
(-7.62)\end{array}$ & $\begin{array}{l}-0.006 \\
(-0.36)\end{array}$ & $\begin{array}{l}-0.002 \\
(-0.11)\end{array}$ & $\begin{array}{c}-0.204 * * * \\
(-8.06)\end{array}$ & $\begin{array}{l}-0.011 \\
(-0.59)\end{array}$ & $\begin{array}{l}-0.011 \\
(-0.50)\end{array}$ \\
\hline ROA & $\begin{array}{c}-0.333 * * * \\
(-5.97)\end{array}$ & $\begin{array}{l}0.069 \\
(1.41)\end{array}$ & $\begin{array}{l}0.108 * \\
(1.77)\end{array}$ & $\begin{array}{c}-0.350 * * * \\
(-5.52)\end{array}$ & $\begin{array}{l}0.079 \\
(1.37)\end{array}$ & $\begin{array}{l}0.120 \\
(1.63)\end{array}$ \\
\hline Intangible & $\begin{array}{l}-0.009 \\
(-0.12)\end{array}$ & $\begin{array}{l}0.022 \\
(0.47)\end{array}$ & $\begin{array}{l}0.018 \\
(0.32)\end{array}$ & $\begin{array}{l}-0.028 \\
(-0.30)\end{array}$ & $\begin{array}{l}0.020 \\
(0.32)\end{array}$ & $\begin{array}{l}0.013 \\
(0.17)\end{array}$ \\
\hline Leverage & $\begin{array}{c}0.142 * * * \\
(6.59)\end{array}$ & $\begin{array}{l}0.019 \\
(1.34)\end{array}$ & $\begin{array}{l}0.033 * \\
(1.92)\end{array}$ & $\begin{array}{c}0.142 * * * \\
(5.87)\end{array}$ & $\begin{array}{l}0.014 \\
(0.89)\end{array}$ & $\begin{array}{l}0.029 \\
(1.45)\end{array}$ \\
\hline Capital Expenditure & $\begin{array}{c}-0.216^{* * *} \\
(-3.97)\end{array}$ & $\begin{array}{l}0.045 \\
(1.12)\end{array}$ & $\begin{array}{l}0.025 \\
(0.52)\end{array}$ & $\begin{array}{c}-0.229 * * * \\
(-3.68)\end{array}$ & $\begin{array}{l}0.051 \\
(1.11)\end{array}$ & $\begin{array}{l}0.028 \\
(0.51)\end{array}$ \\
\hline Tobin's Q & $\begin{array}{l}-0.002 \\
(-1.00)\end{array}$ & $\begin{array}{c}-0.012 * * * \\
(-6.76)\end{array}$ & $\begin{array}{c}-0.014 * * * \\
(-6.63)\end{array}$ & $\begin{array}{l}-0.001 \\
(-0.60)\end{array}$ & $\begin{array}{c}-0.013 * * * \\
(-6.54)\end{array}$ & $\begin{array}{c}-0.015^{* * *} \\
(-6.31)\end{array}$ \\
\hline
\end{tabular}




\begin{tabular}{|c|c|c|c|c|c|c|}
\hline Blockholders & $\begin{array}{c}-0.130^{* * * *} \\
(-5.36)\end{array}$ & $\begin{array}{c}0.027 * * \\
(2.06)\end{array}$ & $\begin{array}{l}0.017 \\
(1.17)\end{array}$ & $\begin{array}{c}-0.136 * * * \\
(-5.24)\end{array}$ & $\begin{array}{l}0.015 \\
(1.00)\end{array}$ & $\begin{array}{l}0.006 \\
(0.38)\end{array}$ \\
\hline \multirow[t]{2}{*}{ Board Size } & $-0.007 * * *$ & 0.001 & 0.001 & $-0.008 * * *$ & 0.001 & 0.000 \\
\hline & $(-3.20)$ & $(0.96)$ & (1.06) & $(-3.19)$ & $(0.61)$ & $(0.21)$ \\
\hline \multirow[t]{2}{*}{ Board Independent } & -0.060 & 0.037 & 0.037 & -0.034 & 0.057 & 0.046 \\
\hline & $(-0.94)$ & (1.06) & $(0.88)$ & $(-0.48)$ & (1.44) & $(0.95)$ \\
\hline \multirow[t]{2}{*}{ SOE } & $-0.192 * * *$ & $-0.012^{* *}$ & $-0.020 * * *$ & $-0.207 * * *$ & $-0.018 * *$ & $-0.023 * * *$ \\
\hline & $(-20.18)$ & $(-2.15)$ & $(-3.07)$ & $(-19.90)$ & $(-2.53)$ & $(-2.66)$ \\
\hline \multirow[t]{2}{*}{ CEO Duality } & -0.001 & 0.003 & 0.001 & -0.003 & 0.006 & 0.004 \\
\hline & $(-0.11)$ & $(0.64)$ & $(0.24)$ & $(-0.28)$ & $(1.03)$ & $(0.63)$ \\
\hline \multirow[t]{2}{*}{ Related } & & -0.004 & -0.005 & & -0.001 & -0.003 \\
\hline & & $(-1.09)$ & $(-1.07)$ & & $(-0.31)$ & $(-0.59)$ \\
\hline \multirow[t]{2}{*}{ Significant } & & $0.035 * * *$ & $0.041 * * *$ & & $0.027 *$ & $0.036^{* *}$ \\
\hline & & $(2.65)$ & $(2.63)$ & & $(1.85)$ & $(2.14)$ \\
\hline \multirow[t]{2}{*}{ Relative Size } & & $0.034 * * *$ & $0.047 * * *$ & & $0.040 * * *$ & $0.052 * * *$ \\
\hline & & $(7.00)$ & $(7.65)$ & & (7.08) & $(7.09)$ \\
\hline \multirow[t]{2}{*}{ Runup_stock } & & $-0.020 * * *$ & $-0.030 * * *$ & & $-0.018 * * *$ & $-0.028 * * *$ \\
\hline & & $(-4.62)$ & $(-6.24)$ & & $(-3.60)$ & $(-4.84)$ \\
\hline \multirow[t]{2}{*}{ Cash Payment } & & $-0.050 * * *$ & $-0.057 * * *$ & & $-0.043 * * *$ & $-0.050 * * *$ \\
\hline & & $(-3.88)$ & $(-3.76)$ & & $(-3.00)$ & $(-2.98)$ \\
\hline \multirow[t]{2}{*}{ Cash Mixed } & & -0.018 & $-0.030^{*}$ & & -0.017 & $-0.035^{*}$ \\
\hline & & $(-1.21)$ & $(-1.71)$ & & $(-1.00)$ & $(-1.75)$ \\
\hline Industry FEs & \multicolumn{6}{|c|}{$\mathrm{Y}$} \\
\hline Year FEs & \multicolumn{6}{|c|}{$\mathrm{Y}$} \\
\hline \multicolumn{4}{|l|}{ Province FEs } & \multicolumn{3}{|c|}{$\mathrm{Y}$} \\
\hline Observations & 19,782 & 4,336 & 4,336 & 16,816 & 3,299 & 3,299 \\
\hline Adjusted R-squared & 0.381 & 0.169 & 0.175 & 0.321 & 0.161 & 0.166 \\
\hline
\end{tabular}


Table 7 Takeover premium and related party transaction

This table reports the effect of stock pledge on M\&A characteristics. Premium is the ratio of the trading value of the target on the estimated value minus one. Related is a dummy that equals 1 if the deal is a related party transaction, and 0 otherwise. Pledge_Dummy is a dummy that equals one if the controlling shareholder of the firm has shares pledged at the end of the year, and zero otherwise. The definition of other controls are listed in Appendix A. The t-statistics in parentheses are based on standard errors adjusted for firm-level clustering. $* * *, * *, *$ represent statistical significance at the $1 \%, 5 \%$ and $10 \%$ levels, respectively.

\begin{tabular}{|c|c|c|}
\hline & $\begin{array}{l}\text { Premium } \\
\text { (1) }\end{array}$ & $\begin{array}{c}\text { Prob(Related) } \\
(2)\end{array}$ \\
\hline Pledge_Dummy & $\begin{array}{c}0.234 * * \\
(2.01)\end{array}$ & $\begin{array}{c}0.074^{*} \\
(1.80)\end{array}$ \\
\hline Size & $\begin{array}{l}0.073 \\
(1.13)\end{array}$ & $\begin{array}{l}0.033 \\
(1.52)\end{array}$ \\
\hline Annual Return & $\begin{array}{l}0.124 \\
(0.83)\end{array}$ & $\begin{array}{c}-0.045^{*} \\
(-1.69)\end{array}$ \\
\hline Cash & $\begin{array}{l}0.122 \\
(0.32)\end{array}$ & $\begin{array}{c}-0.531 * * * \\
(-3.64)\end{array}$ \\
\hline ROA & $\begin{array}{l}0.809 \\
(0.90)\end{array}$ & $\begin{array}{c}-1.168 * * * \\
(-3.46)\end{array}$ \\
\hline Intangible & $\begin{array}{l}-0.317 \\
(-0.26)\end{array}$ & $\begin{array}{l}0.227 \\
(0.59)\end{array}$ \\
\hline Leverage & $\begin{array}{l}-0.04 \\
(-0.14)\end{array}$ & $\begin{array}{l}0.153 \\
(1.36)\end{array}$ \\
\hline Capital Expenditure & $\begin{array}{l}-0.95 \\
(-0.97)\end{array}$ & $\begin{array}{l}-0.226 \\
(-0.63)\end{array}$ \\
\hline Tobin's Q & $\begin{array}{l}-0.022 \\
(-0.51)\end{array}$ & $\begin{array}{c}0.026 * * \\
(2.22)\end{array}$ \\
\hline Blockholders & $\begin{array}{c}0.627 * \\
(1.68)\end{array}$ & $\begin{array}{c}0.528 * * * \\
(4.23)\end{array}$ \\
\hline Board Size & $\begin{array}{l}0.034 \\
(0.94)\end{array}$ & $\begin{array}{c}-0.020 * \\
(-1.71)\end{array}$ \\
\hline Board Independent & $\begin{array}{l}1.690 * \\
(1.70)\end{array}$ & $\begin{array}{l}(0.193) \\
(-0.51)\end{array}$ \\
\hline SOE & $\begin{array}{l}-0.180 \\
(-1.62)\end{array}$ & $\begin{array}{c}0.354 * * * \\
(7.50)\end{array}$ \\
\hline CEO Duality & $\begin{array}{l}0.214 \\
(1.54)\end{array}$ & $\begin{array}{c}-0.203 * * * \\
(-4.66)\end{array}$ \\
\hline Related & $\begin{array}{c}-0.326 * * * \\
(-3.47)\end{array}$ & \\
\hline Significant & $\begin{array}{c}-0.327 * * \\
(-2.41)\end{array}$ & \\
\hline Relative Size & $\begin{array}{l}0.174 \\
(1.45)\end{array}$ & \\
\hline Runup_stock & $\begin{array}{l}0.139 \\
(0.93)\end{array}$ & \\
\hline Cash Payment & $\begin{array}{l}0.263 \\
(1.48)\end{array}$ & \\
\hline Cash Mixed & $\begin{array}{c}-0.316 * * \\
(-2.22)\end{array}$ & \\
\hline Industry FEs & & $\mathrm{Y}$ \\
\hline Year FEs & & $\mathrm{Y}$ \\
\hline Province FEs & & $\mathrm{Y}$ \\
\hline Observations & 3,311 & 6,540 \\
\hline Pseudo /Adjusted R-squared & 0.030 & 0.079 \\
\hline
\end{tabular}


Table 8 Cross-sectional tests

This table reports the cross-sectional tests on SOE and free cash flow. CAR $[-3,+3]($ CAR $[-5,+5])$ is defined the same as that of Table 3. Pledge_Dummy is a dummy that equals one if the controlling shareholder of the firm has shares pledged at the end of the year, and zero otherwise. SOE is a dummy variable that equals one if the firm is state-owned in a given year, and zero otherwise. FCF_High is a dummy that equals 1 if the free cash flow to total assets ratio of the firm ranks top $20 \%$ in the industry of a given year, and 0 otherwise. The definition of other controls are listed in Appendix A. The regressions include industry, year and province fixed effects. The t-statistics in parentheses are based on standard errors adjusted for firm-level clustering. ***, **, * represent statistical significance at the $1 \%, 5 \%$ and $10 \%$ levels, respectively.

\begin{tabular}{|c|c|c|c|c|}
\hline & \multicolumn{2}{|c|}{ SOE } & \multicolumn{2}{|c|}{ Free Cash Flow } \\
\hline & $\begin{array}{c}\text { CAR }[-3,+3] \\
(1)\end{array}$ & $\begin{array}{c}\text { CAR }[-5,+5] \\
(2)\end{array}$ & $\begin{array}{c}\text { CAR }[-3,+3] \\
\text { (3) }\end{array}$ & $\begin{array}{c}\text { CAR }[-5,+5] \\
(4)\end{array}$ \\
\hline SOE * Pledge_Dummy & $\begin{array}{c}0.015^{* *} \\
(2.00)\end{array}$ & $\begin{array}{c}0.016^{*} \\
(1.78)\end{array}$ & & \\
\hline FCF_High * Pledge_Dummy & & & $\begin{array}{l}-0.013 \\
(-1.46)\end{array}$ & $\begin{array}{c}-0.022 * * \\
(-2.16)\end{array}$ \\
\hline FCF_High & & & $\begin{array}{l}0.005 \\
(1.08)\end{array}$ & $\begin{array}{c}0.009^{*} \\
(1.69)\end{array}$ \\
\hline Pledge_Dummy & $\begin{array}{c}-0.012 * * * \\
(-2.59)\end{array}$ & $\begin{array}{c}-0.014 * * \\
(-2.42)\end{array}$ & $\begin{array}{l}-0.005 \\
(-1.23)\end{array}$ & $\begin{array}{l}-0.004 \\
(-0.80)\end{array}$ \\
\hline Size & $\begin{array}{c}-0.013 * * * \\
(-6.09)\end{array}$ & $\begin{array}{c}-0.014 * * * \\
(-5.55)\end{array}$ & $\begin{array}{c}-0.013 * * * \\
(-6.08)\end{array}$ & $\begin{array}{c}-0.014 * * * \\
(-5.55)\end{array}$ \\
\hline Annual Return & $\begin{array}{c}0.005^{*} \\
(1.75)\end{array}$ & $\begin{array}{l}0.005 \\
(1.30)\end{array}$ & $\begin{array}{l}0.002 \\
(0.69)\end{array}$ & $\begin{array}{l}0.001 \\
(0.17)\end{array}$ \\
\hline Cash & $\begin{array}{l}0.008 \\
(0.56)\end{array}$ & $\begin{array}{l}0.015 \\
(0.88)\end{array}$ & $\begin{array}{l}0.018 \\
(1.13)\end{array}$ & $\begin{array}{l}0.024 \\
(1.29)\end{array}$ \\
\hline ROA & $\begin{array}{l}0.076^{*} \\
(1.85)\end{array}$ & $\begin{array}{c}0.105 * * \\
(2.05)\end{array}$ & $\begin{array}{l}0.057 \\
(1.39)\end{array}$ & $\begin{array}{l}0.086^{*} \\
(1.67)\end{array}$ \\
\hline Intangible & $\begin{array}{l}0.011 \\
(0.28)\end{array}$ & $\begin{array}{l}0.001 \\
(0.02)\end{array}$ & $\begin{array}{l}0.025 \\
(0.66)\end{array}$ & $\begin{array}{l}0.016 \\
(0.33)\end{array}$ \\
\hline Leverage & $\begin{array}{l}0.016 \\
(1.37)\end{array}$ & $\begin{array}{l}0.027^{*} \\
(1.88)\end{array}$ & $\begin{array}{l}0.019 \\
(1.56)\end{array}$ & $\begin{array}{c}0.030 * * \\
(2.02)\end{array}$ \\
\hline Capital Expenditure & $\begin{array}{l}0.037 \\
(1.10)\end{array}$ & $\begin{array}{l}0.017 \\
(0.45)\end{array}$ & $\begin{array}{l}0.040 \\
(1.12)\end{array}$ & $\begin{array}{l}0.020 \\
(0.48)\end{array}$ \\
\hline Tobin's Q & $\begin{array}{c}-0.011 * * * \\
(-6.81)\end{array}$ & $\begin{array}{c}-0.012 * * * \\
(-6.38)\end{array}$ & $\begin{array}{c}-0.010 * * * \\
(-6.63)\end{array}$ & $\begin{array}{c}-0.011 * * * \\
(-6.30)\end{array}$ \\
\hline Blockholders & $\begin{array}{c}0.021^{*} \\
(1.90)\end{array}$ & $\begin{array}{l}0.017 \\
(1.30)\end{array}$ & $\begin{array}{c}0.023 * * \\
(2.01)\end{array}$ & $\begin{array}{l}0.019 \\
(1.43)\end{array}$ \\
\hline Board Size & $\begin{array}{l}0.001 \\
(1.42)\end{array}$ & $\begin{array}{l}0.002 \\
(1.48)\end{array}$ & $\begin{array}{l}0.002 \\
(1.45)\end{array}$ & $\begin{array}{l}0.002 \\
(1.40)\end{array}$ \\
\hline Board Independent & $\begin{array}{l}0.046 \\
(1.47)\end{array}$ & $\begin{array}{l}0.043 \\
(1.14)\end{array}$ & $\begin{array}{l}0.046 \\
(1.42)\end{array}$ & $\begin{array}{l}0.048 \\
(1.23)\end{array}$ \\
\hline SOE & $\begin{array}{c}-0.011 * * \\
(-2.27)\end{array}$ & $\begin{array}{c}-0.016 * * * \\
(-2.83)\end{array}$ & $\begin{array}{l}-0.007 \\
(-1.56)\end{array}$ & $\begin{array}{c}-0.011 * * \\
(-2.23)\end{array}$ \\
\hline CEO Duality & $\begin{array}{l}0.004 \\
(0.99)\end{array}$ & $\begin{array}{l}0.004 \\
(0.70)\end{array}$ & $\begin{array}{l}0.005 \\
(1.13)\end{array}$ & $\begin{array}{l}0.004 \\
(0.77)\end{array}$ \\
\hline Related & $\begin{array}{l}-0.003 \\
(-0.90)\end{array}$ & $\begin{array}{l}-0.003 \\
(-0.78)\end{array}$ & $\begin{array}{l}-0.003 \\
(-0.78)\end{array}$ & $\begin{array}{l}-0.003 \\
(-0.77)\end{array}$ \\
\hline Significant & $\begin{array}{c}0.038 * * * \\
(3.32)\end{array}$ & $\begin{array}{c}0.042 * * * \\
(3.13)\end{array}$ & $\begin{array}{c}0.036 * * * \\
(3.05)\end{array}$ & $\begin{array}{c}0.040 * * * \\
(2.95)\end{array}$ \\
\hline Relative Size & $\begin{array}{c}0.028 * * * \\
(6.49)\end{array}$ & $\begin{array}{c}0.040 * * * \\
(7.41)\end{array}$ & $\begin{array}{c}0.028 * * * \\
(6.29)\end{array}$ & $\begin{array}{c}0.040 * * * \\
(7.22)\end{array}$ \\
\hline Runup_stock & $\begin{array}{c}-0.022 * * * \\
(-6.07)\end{array}$ & $\begin{array}{c}-0.033 * * * \\
(-7.89)\end{array}$ & $\begin{array}{c}-0.021 * * * \\
(-5.59)\end{array}$ & $\begin{array}{c}-0.032 * * * \\
(-7.29)\end{array}$ \\
\hline Cash Payment & $\begin{array}{c}-0.061 * * * \\
(-5.52)\end{array}$ & $\begin{array}{c}-0.069 * * * \\
(-5.32)\end{array}$ & $\begin{array}{c}-0.059 * * * \\
(-5.27)\end{array}$ & $\begin{array}{c}-0.066 * * * \\
(-5.06)\end{array}$ \\
\hline Cash Mixed & $\begin{array}{c}-0.027 * * \\
(-2.07)\end{array}$ & $\begin{array}{c}-0.038 * * \\
(-2.48)\end{array}$ & $\begin{array}{c}-0.024 * \\
(-1.80)\end{array}$ & $\begin{array}{c}-0.035^{* *} * \\
(-2.20)\end{array}$ \\
\hline $\begin{array}{l}\text { Industry FEs } \\
\text { Year FEs } \\
\text { Province FEs }\end{array}$ & & $\begin{array}{l}\mathrm{Y} \\
\mathrm{Y} \\
\mathrm{Y}\end{array}$ & & \\
\hline Observations & 5,532 & 5,532 & 5,243 & 5,243 \\
\hline Adjusted R-squared & 0.173 & 0.182 & 0.172 & 0.181 \\
\hline
\end{tabular}


Table 9 Stock pledge and Post-M\&A accounting performance

This table reports the effect of stock pledge on the post-M\&A accounting performance. ROA $+1 \mathrm{y} / 2 \mathrm{y} / 3 \mathrm{y}$ is the industry adjusted return on assets 1/2/3 year(s) after M\&A announcement year. Pledge_Dummy is a dummy that equals one if the controlling shareholder of the firm has shares pledged at the end of the year, and zero otherwise. The definition of other controls are listed in Appendix A. The regressions include industry, year and province fixed effects. The t-statistics in parentheses are based on standard errors adjusted for firm-level clustering. $* * *, * *, *$ represent statistical significance at the $1 \%, 5 \%$ and $10 \%$ levels, respectively.

\begin{tabular}{|c|c|c|c|}
\hline & $\mathrm{ROA}+1 \mathrm{y}$ & $\mathrm{ROA}+2 \mathrm{y}$ & $\mathrm{ROA}+3 \mathrm{y}$ \\
\hline & $(1)$ & $(2)$ & (3) \\
\hline \multirow[t]{2}{*}{ Pledge_Dummy } & $-0.004 * *$ & $-0.008 * * *$ & $-0.008 * * *$ \\
\hline & $(-1.99)$ & $(-3.21)$ & $(-2.64)$ \\
\hline \multirow[t]{2}{*}{ Size } & $0.003 * * *$ & $0.004 * * *$ & $0.004 * * *$ \\
\hline & (2.64) & (2.69) & $(2.62)$ \\
\hline \multirow[t]{2}{*}{ Annual Return } & 0.001 & -0.000 & -0.000 \\
\hline & $(0.28)$ & $(-0.06)$ & $(-0.16)$ \\
\hline \multirow[t]{2}{*}{ Cash } & $0.038 * * *$ & $0.024 * *$ & 0.011 \\
\hline & $(4.88)$ & $(2.51)$ & $(0.93)$ \\
\hline \multirow[t]{2}{*}{ Intangible } & $0.032 *$ & $0.037 *$ & -0.024 \\
\hline & $(1.66)$ & $(1.68)$ & $(-0.77)$ \\
\hline \multirow[t]{2}{*}{ Leverage } & -0.006 & -0.008 & -0.011 \\
\hline & $(-0.84)$ & $(-1.04)$ & $(-1.27)$ \\
\hline \multirow[t]{2}{*}{ Capital Expenditure } & -0.009 & -0.022 & -0.009 \\
\hline & $(-0.49)$ & $(-1.11)$ & $(-0.35)$ \\
\hline \multirow[t]{2}{*}{ Tobin's Q } & $0.003 * * *$ & 0.001 & $0.003 * *$ \\
\hline & (3.88) & $(1.24)$ & $(2.34)$ \\
\hline \multirow[t]{2}{*}{ Blockholders } & $0.026 * * *$ & 0.010 & $0.016^{*}$ \\
\hline & (4.15) & $(1.55)$ & $(1.91)$ \\
\hline \multirow[t]{2}{*}{ Board Size } & -0.000 & $-0.001 *$ & -0.000 \\
\hline & $(-0.62)$ & $(-1.71)$ & $(-0.59)$ \\
\hline \multirow[t]{2}{*}{ Board Independent } & $-0.064 * * *$ & $-0.035^{*}$ & -0.033 \\
\hline & $(-3.29)$ & $(-1.77)$ & $(-1.40)$ \\
\hline \multirow[t]{2}{*}{ SOE } & 0.000 & -0.001 & -0.003 \\
\hline & $(0.09)$ & $(-0.44)$ & $(-0.89)$ \\
\hline \multirow[t]{2}{*}{ CEO Duality } & $-0.004 *$ & 0.000 & 0.003 \\
\hline & $(-1.69)$ & $(0.06)$ & $(0.75)$ \\
\hline \multirow[t]{2}{*}{ Related } & 0.001 & 0.002 & -0.001 \\
\hline & $(0.78)$ & $(0.78)$ & $(-0.32)$ \\
\hline \multirow[t]{2}{*}{ Significant } & $0.008 *$ & 0.006 & $-0.014 * *$ \\
\hline & $(1.82)$ & (1.24) & $(-1.99)$ \\
\hline \multirow[t]{2}{*}{ Relative Size } & $0.004 * *$ & $0.006 * * *$ & 0.003 \\
\hline & $(2.03)$ & (3.16) & $(1.37)$ \\
\hline \multirow[t]{2}{*}{ Runup_stock } & 0.001 & -0.001 & -0.001 \\
\hline & $(0.56)$ & $(-0.63)$ & $(-0.58)$ \\
\hline \multirow[t]{2}{*}{ Cash Payment } & $-0.012 * * *$ & -0.008 & $-0.018 * * *$ \\
\hline & $(-3.09)$ & $(-1.56)$ & $(-2.98)$ \\
\hline \multirow[t]{2}{*}{ Cash Mixed } & $-0.015 * * *$ & $-0.016 * * *$ & $-0.026 * * *$ \\
\hline & $(-3.65)$ & $(-2.65)$ & $(-3.21)$ \\
\hline \multirow[t]{2}{*}{ ROA -1y } & $0.287 * * *$ & $0.254 * * *$ & $0.140 * * *$ \\
\hline & $(11.74)$ & $(9.04)$ & (3.82) \\
\hline \multirow[t]{2}{*}{ ROA $-2 y$} & $0.096 * * *$ & $0.068 * *$ & $0.096 * *$ \\
\hline & (3.30) & $(2.27)$ & $(2.43)$ \\
\hline ROA -3y & 0.037 & $0.095 * * *$ & 0.041 \\
\hline & $(1.58)$ & $(3.56)$ & $(1.32)$ \\
\hline Industry FEs & & $\mathrm{Y}$ & \\
\hline Year FEs & & $\mathrm{Y}$ & \\
\hline Province FEs & & $\mathrm{Y}$ & \\
\hline Observations & 4,182 & 3,707 & 3,207 \\
\hline Adjusted R-squared & 0.176 & 0.138 & 0.100 \\
\hline
\end{tabular}


Table 10 Stock pledge and Post-M\&A goodwill impairment

This table reports the effect of stock pledge on the post-M\&A goodwill impairment with the Probit model. Impairment_Dummy is a dummy that equals 1 if the firm reports goodwill impairment during three years after the M\&A announcement, and 0 otherwise. Pledge_Dummy is a dummy that equals one if the controlling shareholder of the firm has shares pledged at the end of the year, and zero otherwise. The sample covers the M\&A deals from 2006 to 2015. The definition of other controls are listed in Appendix A. The regressions include industry, year and province fixed effects. The t-statistics in parentheses are based on standard errors adjusted for firm-level clustering. $* * *, * *, *$ represent statistical significance at the $1 \%, 5 \%$ and $10 \%$ levels, respectively.

\begin{tabular}{|c|c|}
\hline & Prob (Impairment_Dummy) \\
\hline Pledge_Dummy & $\begin{array}{c}0.369^{* *} \\
(2.53)\end{array}$ \\
\hline Size & $\begin{array}{l}0.050 \\
(0.50)\end{array}$ \\
\hline Annual Return & $\begin{array}{l}-0.145 \\
(-0.82)\end{array}$ \\
\hline Cash & $\begin{array}{l}0.462 \\
(0.91)\end{array}$ \\
\hline ROA & $\begin{array}{l}1.175 \\
(0.73)\end{array}$ \\
\hline Intangible & $\begin{array}{l}0.754 \\
(0.59)\end{array}$ \\
\hline Leverage & $\begin{array}{c}-1.004 * * \\
(-2.29)\end{array}$ \\
\hline Capital Expenditure & $\begin{array}{l}-1.934 \\
(-1.54)\end{array}$ \\
\hline Tobin's Q & $\begin{array}{l}-0.067 \\
(-1.10)\end{array}$ \\
\hline Blockholders & $\begin{array}{c}-1.437 * * \\
(-2.29)\end{array}$ \\
\hline Board Size & $\begin{array}{l}-0.019 \\
(-0.38)\end{array}$ \\
\hline Board independent & $\begin{array}{l}-2.086 \\
(-1.23)\end{array}$ \\
\hline SOE & $\begin{array}{l}0.183 \\
(0.86)\end{array}$ \\
\hline CEO Duality & $\begin{array}{l}-0.087 \\
(-0.51)\end{array}$ \\
\hline Related & $\begin{array}{l}0.055 \\
(0.36)\end{array}$ \\
\hline Significant & $\begin{array}{l}-0.028 \\
(-0.13)\end{array}$ \\
\hline Relative Size & $\begin{array}{c}-0.287 * * \\
(-2.09)\end{array}$ \\
\hline Runup_stock & $\begin{array}{r}0.220^{*} \\
(1.73)\end{array}$ \\
\hline Cash Payment & $\begin{array}{l}-0.056 \\
(-0.17)\end{array}$ \\
\hline Cash Mixed & $\begin{array}{l}0.407 \\
(1.27)\end{array}$ \\
\hline Industry FEs & $\mathrm{Y}$ \\
\hline Year FEs & $\mathrm{Y}$ \\
\hline Province FEs & Y \\
\hline Observations & 1,075 \\
\hline Pseudo R-squared & 0.220 \\
\hline
\end{tabular}




\section{Appendix A: Variable definitions}

\begin{tabular}{|c|c|}
\hline Variable & Definition \\
\hline Annual Return & Annual stock returns. \\
\hline Blockholders & Percentage of shares owned by the controlling shareholder. \\
\hline Board Independent & The ratio of the number of independent board members to the total number of board members. \\
\hline Board Size & The total number of directors on board. \\
\hline Capital Expenditure & The capital expenditure scaled by the total assets. \\
\hline CAR $[-3,+3]$ & $\begin{array}{l}\text { Cumulative abnormal returns in the } 7 \text {-day }[-3,+3] \text { event window using the market model with } \\
\text { parameters estimated over the } 200 \text { trading days ending } 61 \text { days prior to the deal announcement date. }\end{array}$ \\
\hline CAR $[-5,+5]$ & $\begin{array}{l}\text { Cumulative abnormal returns in the } 11 \text {-day }[-5,+5] \text { event window using the market model with } \\
\text { parameters estimated over the } 200 \text { trading days ending } 61 \text { days prior to the deal announcement date. }\end{array}$ \\
\hline Cash & Cash and cash equivalent to total assets. \\
\hline Cash Mixed & $\begin{array}{l}\text { A dummy variable that equals one if the payment involves cash and other types of payment, and } \\
\text { zero otherwise. }\end{array}$ \\
\hline Cash Payment & A dummy variable that equals one if the payment is pure cash, and zero otherwise. \\
\hline CEO Duality & A dummy variable that equals one if the CEO is also the chair of the board, and zero otherwise. \\
\hline Intangible & Intangible assets divided by total assets. \\
\hline Leverage & Total debt divided by total assets. \\
\hline $\mathrm{M} \& \mathrm{~A}$ & A dummy that equals one if the firm announces a merger and acquisition, and zero otherwise. \\
\hline Significant & A dummy that equals one if the deal is a significant deal, and 0 otherwise. \\
\hline Pledge_Dummy & $\begin{array}{l}\text { A dummy that equals one if the controlling shareholder of the firm has shares pledged at the end of } \\
\text { the year, and zero otherwise. }\end{array}$ \\
\hline Premium & The ratio of trading value of the target on the estimated value minus one. \\
\hline Related & A dummy that equals one if the deal is a related party transaction, and 0 otherwise. \\
\hline Relative Size & Deal value divided by the acquirer's total assets. \\
\hline ROA & Return on assets. \\
\hline $\mathrm{ROA}+1 \mathrm{y} / 2 \mathrm{y} / 3 \mathrm{y}$ & Industry adjusted ROA $1 / 2 / 3$ year(s) after M\&A announcement year. \\
\hline ROA $-1 y / 2 y / 3 y$ & Industry adjusted ROA 1/2/3 year(s) before M\&A announcement year. \\
\hline Runup_stock & $\begin{array}{l}\text { Buy and hold daily Shanghai and Shenzhen value-weighted stock returns over the } 200 \text { trading days } \\
\text { ending } 61 \text { days prior to the deal announcement date. }\end{array}$ \\
\hline Size & Natural logarithm of total assets. \\
\hline SOE & A dummy variable that equals one if the firm is state-owned in a given year, and zero otherwise. \\
\hline Tobin's Q & The sum of the market value of equity and total liabilities divided by total assets \\
\hline
\end{tabular}


Appendix B: Robustness tests on M\&A tendency

This table reports the robustness tests of M\&A tendency based on the Probit model. M\&A is a dummy that equals one if the firm announces a merger and acquisition, and zero otherwise. Pledge_Dummy is a dummy that equals one if the controlling shareholder of the firm has shares pledged at the end of the year, and zero otherwise. Column (1) uses the percentage of shares pledged by the controlling shareholders (Pledge Percent) as the independent variable. Column (2) uses firm and year FEs. Column (3) drops ST stocks. Column (4) drops small transactions with the deal value less than $1 \%$ of the acquirer's total assets. Column (5) drop SOEs. Column (5) includes sample with multiple deals announced during one year (but exclude sample with multiple deals announced during $[-5,+5]$ day window). The definition of other controls are listed in Appendix A. The regressions (except for column (1) and (2)) include industry, year and province fixed effects. The t-statistics in parentheses are based on standard errors adjusted for firm-level clustering. ***, **, * represent statistical significance at the $1 \%, 5 \%$ and $10 \%$ levels, respectively.

\begin{tabular}{|c|c|c|c|c|c|c|}
\hline & \multicolumn{6}{|c|}{ Prob(M\&A) } \\
\hline & $\begin{array}{c}\text { Pledge Percent } \\
\text { (1) }\end{array}$ & $\begin{array}{c}\text { Firm and Year FEs } \\
(2)\end{array}$ & $\begin{array}{c}\text { Drop ST Stocks } \\
(3)\end{array}$ & $\begin{array}{c}\text { Drop Small Deals } \\
(4)\end{array}$ & $\begin{array}{c}\text { Drop SOEs } \\
(5) \\
\end{array}$ & $\begin{array}{c}\text { Expanded Sample } \\
(6)\end{array}$ \\
\hline Pledge_Dummy & & $\begin{array}{c}0.106 * * * \\
(3.18)\end{array}$ & $\begin{array}{c}0.135^{* * *} \\
(5.72)\end{array}$ & $\begin{array}{c}0.143 * * * \\
(5.93)\end{array}$ & $\begin{array}{c}0.152 * * * \\
(5.22)\end{array}$ & $\begin{array}{c}0.180^{* * *} \\
(8.35)\end{array}$ \\
\hline Pledge_Percent & $\begin{array}{c}0.162 * * * \\
(4.90)\end{array}$ & & & & & \\
\hline Size & $\begin{array}{c}0.028 * * \\
(2.46)\end{array}$ & $\begin{array}{l}-0.000 \\
(-0.01)\end{array}$ & $\begin{array}{c}0.025^{* *} \\
(2.03)\end{array}$ & $\begin{array}{c}-0.037 * * * \\
(-2.93)\end{array}$ & $\begin{array}{l}0.010 \\
(0.61)\end{array}$ & $\begin{array}{c}0.071^{* * *} \\
(6.05)\end{array}$ \\
\hline Annual Return & $\begin{array}{c}0.035^{* *} \\
(2.52)\end{array}$ & $\begin{array}{l}-0.016 \\
(-0.74)\end{array}$ & $\begin{array}{c}0.035^{* *} \\
(2.39)\end{array}$ & $\begin{array}{c}0.031^{* *} \\
(2.15)\end{array}$ & $\begin{array}{c}0.036^{* * *} \\
(2.14)\end{array}$ & $\begin{array}{c}0.058 * * * \\
(4.85)\end{array}$ \\
\hline Cash & $\begin{array}{c}0.156^{* *} \\
(2.10)\end{array}$ & $\begin{array}{c}0.256^{* *} \\
(2.23)\end{array}$ & $\begin{array}{c}0.171 * * \\
(2.24)\end{array}$ & $\begin{array}{c}0.228 * * * \\
(2.91)\end{array}$ & $\begin{array}{l}0.131 \\
(1.40)\end{array}$ & $\begin{array}{c}0.237 * * * \\
(3.37)\end{array}$ \\
\hline ROA & $\begin{array}{c}0.817 * * * \\
(4.65)\end{array}$ & $\begin{array}{c}0.698 * * * \\
(2.94)\end{array}$ & $\begin{array}{c}0.806 * * * \\
(4.01)\end{array}$ & $\begin{array}{l}0.593 * * * \\
(3.19)\end{array}$ & $\begin{array}{l}0.721 * * * \\
(3.14)\end{array}$ & $\begin{array}{l}0.941 * * * \\
(5.76)\end{array}$ \\
\hline Intangible & $\begin{array}{l}-0.263 \\
(-1.33)\end{array}$ & $\begin{array}{c}-0.895 * * * \\
(-2.92)\end{array}$ & $\begin{array}{l}-0.281 \\
(-1.30)\end{array}$ & $\begin{array}{l}-0.346 \\
(-1.62)\end{array}$ & $\begin{array}{l}-0.185 \\
(-0.63)\end{array}$ & $\begin{array}{l}-0.068 \\
(-0.38)\end{array}$ \\
\hline Leverage & $\begin{array}{l}-0.060 \\
(-1.05)\end{array}$ & $\begin{array}{c}-0.282 * * * \\
(-2.87)\end{array}$ & $\begin{array}{l}-0.007 \\
(-0.11)\end{array}$ & $\begin{array}{c}-0.115^{*} \\
(-1.90)\end{array}$ & $\begin{array}{l}-0.098 \\
(-1.28)\end{array}$ & $\begin{array}{l}-0.019 \\
(-0.34)\end{array}$ \\
\hline Capital Expenditure & $\begin{array}{l}-0.078 \\
(-0.43)\end{array}$ & $\begin{array}{l}-0.323 \\
(-1.24)\end{array}$ & $\begin{array}{l}-0.126 \\
(-0.67)\end{array}$ & $\begin{array}{l}0.026 \\
(0.13)\end{array}$ & $\begin{array}{c}-0.488 * * \\
(-2.00)\end{array}$ & $\begin{array}{l}0.011 \\
(0.07)\end{array}$ \\
\hline Tobin's Q & $\begin{array}{l}-0.008 \\
(-1.27)\end{array}$ & $\begin{array}{c}0.020 * * \\
(2.06)\end{array}$ & $\begin{array}{l}-0.006 \\
(-0.80)\end{array}$ & $\begin{array}{l}-0.003 \\
(-0.43)\end{array}$ & $\begin{array}{l}-0.012 \\
(-1.55)\end{array}$ & $\begin{array}{l}-0.002 \\
(-0.38)\end{array}$ \\
\hline Blockholders & $\begin{array}{l}-0.066 \\
(-0.97)\end{array}$ & $\begin{array}{l}0.119 \\
(0.75)\end{array}$ & $\begin{array}{l}-0.092 \\
(-1.29)\end{array}$ & $\begin{array}{l}-0.058 \\
(-0.79)\end{array}$ & $\begin{array}{l}0.064 \\
(0.66)\end{array}$ & $\begin{array}{l}-0.053 \\
(-0.78)\end{array}$ \\
\hline Board Size & $\begin{array}{l}-0.011^{*} \\
(-1.81)\end{array}$ & $\begin{array}{l}-0.000 \\
(-0.01)\end{array}$ & $\begin{array}{l}-0.011^{*} \\
(-1.72)\end{array}$ & $\begin{array}{c}-0.018 * * * \\
(-2.69)\end{array}$ & $\begin{array}{l}-0.012 \\
(-1.20)\end{array}$ & $\begin{array}{c}-0.014 * * \\
(-2.24)\end{array}$ \\
\hline Board independent & $\begin{array}{l}-0.033 \\
(-0.17)\end{array}$ & $\begin{array}{l}0.312 \\
(1.00)\end{array}$ & $\begin{array}{l}-0.060 \\
(-0.30)\end{array}$ & $\begin{array}{l}-0.180 \\
(-0.83)\end{array}$ & $\begin{array}{l}0.033 \\
(0.11)\end{array}$ & $\begin{array}{l}-0.073 \\
(-0.39)\end{array}$ \\
\hline SOE & $\begin{array}{c}-0.128 * * * \\
(-4.99)\end{array}$ & $\begin{array}{l}-0.063 \\
(-0.96)\end{array}$ & $\begin{array}{c}-0.128 * * * \\
(-4.84)\end{array}$ & $\begin{array}{c}-0.131 * * * \\
(-4.88)\end{array}$ & & $\begin{array}{c}-0.169 * * * \\
(-6.85)\end{array}$ \\
\hline CEO Duality & $\begin{array}{l}0.011 \\
(0.46)\end{array}$ & $\begin{array}{l}-0.023 \\
(-0.59)\end{array}$ & $\begin{array}{l}0.013 \\
(0.54)\end{array}$ & $\begin{array}{l}0.009 \\
(0.35)\end{array}$ & $\begin{array}{l}-0.011 \\
(-0.39)\end{array}$ & $\begin{array}{l}0.011 \\
(0.46)\end{array}$ \\
\hline $\begin{array}{l}\text { Industry FEs } \\
\text { Year FEs }\end{array}$ & $\begin{array}{l}\mathrm{Y} \\
\mathrm{Y}\end{array}$ & $\mathrm{Y}$ & & & & \\
\hline
\end{tabular}


Province FEs

Firm FEs

Observations

Pseudo R-squared

25,757

0.0231

$\mathrm{Y}$

22,726

0.111

4,038

0.0205

(3,433

0.0259

30,046 0.0333 


\section{Appendix C: Pseudo event years - CAR}

This table reports results with pseudo event years for CAR. The treatment and control are defined the same as that of Table 5. CAR $[-3,+3]($ CAR $[-5,+5])$ is the cumulative abnormal returns in the 7 -day $[-3,+3](11$-day $[-5,+5])$ event window using the market model with parameters estimated over the 200 trading days ending 61 days prior to the deal announcement date. Treat is a dummy variable that equals 1 if the firm belongs to the treatment group, and 0 otherwise. In column (1) and (2), the sample covers the year 2008-2009 and 2011-2012. Post is a dummy variable that equals 1 if the observation is after 2010, and 0 otherwise. In column (3) and (4), the sample covers the year 2014-2017. Post is a dummy variable that equals 1 if the observation is in year 2014-2015, and 0 otherwise. The definition of other controls are listed in Appendix A. The regressions include industry, year and province fixed effects. The t-statistics in parentheses are based on standard errors adjusted for firm-level clustering. ***, **, * represent statistical significance at the $1 \%, 5 \%$ and $10 \%$ levels, respectively.

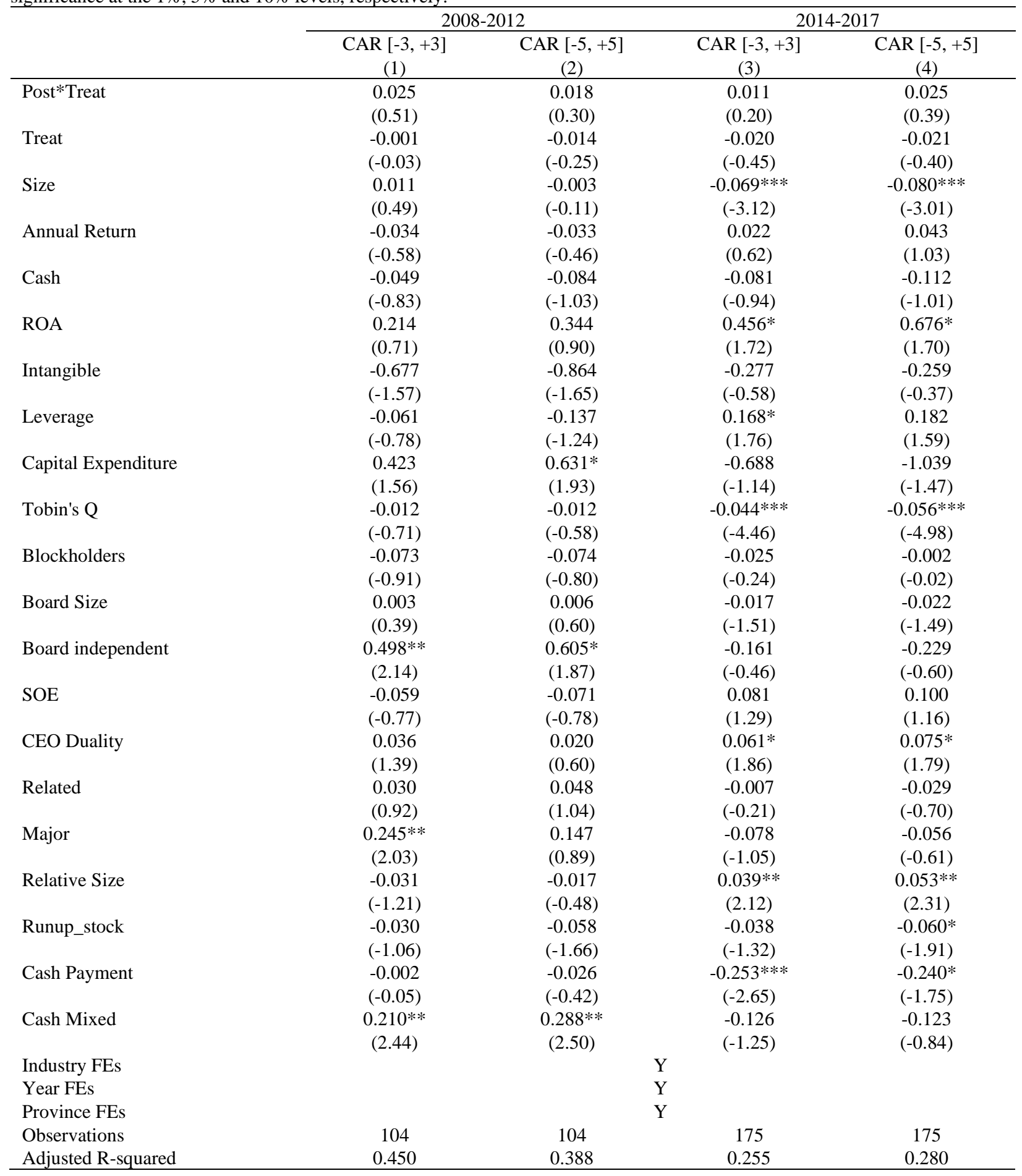




\section{Appendix D: Difference in differences approach for M\&A tendency}

This table reports DID results for M\&A tendency. The treatment and control are defined the same as that of Table 5. M\&A is a dummy that equals one if the firm announces a merger and acquisition, and zero otherwise. Treat is a dummy variable that equals 1 if the firm belongs to the treatment group, and 0 otherwise. Column (1) reports the DID results. Post is a dummy variable that equals 1 if the observation is after 2013, and 0 otherwise. Column (2) and (3) report the results with pseudo event years. In column (2), the sample covers the year 2008-2009 and 2011-2012. Post is a dummy variable that equals 1 if the observation is after 2010, and 0 otherwise. In column (3), the sample covers the year 2014-2017. Post is a dummy variable that equals 1 if the observation is in year 2014-2015, and 0 otherwise. The definition of other controls are listed in Appendix A. The regressions include industry, year and province fixed effects. The t-statistics in parentheses are based on standard errors adjusted for firm-level clustering. $* * *$, **, * represent statistical significance at the $1 \%, 5 \%$ and $10 \%$ levels, respectively.

\begin{tabular}{|c|c|c|c|}
\hline & \multicolumn{3}{|c|}{ Prob(M\&A) } \\
\hline & DID & \multicolumn{2}{|c|}{ Pseudo event years } \\
\hline & $\begin{array}{c}2011-2015 \\
\text { (1) }\end{array}$ & $\begin{array}{c}2008-2012 \\
\text { (2) }\end{array}$ & $\begin{array}{c}\text { 2014-2017 } \\
\text { (3) }\end{array}$ \\
\hline Post*Treat & $\begin{array}{c}0.413 * * * \\
(2.77)\end{array}$ & $\begin{array}{l}-0.107 \\
(-0.73)\end{array}$ & $\begin{array}{l}-0.011 \\
(-0.07)\end{array}$ \\
\hline Treat & $\begin{array}{l}0.067 \\
(0.72)\end{array}$ & $\begin{array}{l}0.120 \\
(1.16)\end{array}$ & $\begin{array}{l}-0.018 \\
(-0.19)\end{array}$ \\
\hline Annual Return & $\begin{array}{c}0.244^{*} \\
(1.67)\end{array}$ & $\begin{array}{l}-0.032 \\
(-0.17)\end{array}$ & $\begin{array}{l}0.100 \\
(0.80)\end{array}$ \\
\hline Cash & $\begin{array}{l}0.697^{*} \\
(1.80)\end{array}$ & $\begin{array}{l}0.362 \\
(0.85)\end{array}$ & $\begin{array}{l}0.574 \\
(1.25)\end{array}$ \\
\hline ROA & $\begin{array}{l}0.701 \\
(0.50)\end{array}$ & $\begin{array}{l}1.892 \\
(1.16)\end{array}$ & $\begin{array}{l}-0.123 \\
(-0.09)\end{array}$ \\
\hline Intangible & $\begin{array}{l}-1.189 \\
(-0.70)\end{array}$ & $\begin{array}{l}-2.700 \\
(-1.18)\end{array}$ & $\begin{array}{c}-2.919 * \\
(-1.74)\end{array}$ \\
\hline Leverage & $\begin{array}{c}-0.664^{*} \\
(-1.66)\end{array}$ & $\begin{array}{c}-1.065^{* *} \\
(-2.55)\end{array}$ & $\begin{array}{l}0.189 \\
(0.50)\end{array}$ \\
\hline Capital Expenditure & $\begin{array}{l}-1.391 \\
(-1.20)\end{array}$ & $\begin{array}{l}-0.743 \\
(-0.55)\end{array}$ & $\begin{array}{c}-3.493 * * * \\
(-2.77)\end{array}$ \\
\hline Tobin's Q & $\begin{array}{l}-0.021 \\
(-0.40)\end{array}$ & $\begin{array}{l}0.037 \\
(0.59)\end{array}$ & $\begin{array}{l}-0.007 \\
(-0.17)\end{array}$ \\
\hline Blockholders & $\begin{array}{l}-0.128 \\
(-0.29)\end{array}$ & $\begin{array}{l}-0.333 \\
(-0.63)\end{array}$ & $\begin{array}{l}0.604 \\
(1.40)\end{array}$ \\
\hline Board Size & $\begin{array}{l}0.062 \\
(1.12)\end{array}$ & $\begin{array}{l}0.103^{*} \\
(1.67)\end{array}$ & $\begin{array}{l}-0.023 \\
(-0.36)\end{array}$ \\
\hline Board independent & $\begin{array}{l}1.690 \\
(1.26)\end{array}$ & $\begin{array}{l}0.443 \\
(0.29)\end{array}$ & $\begin{array}{l}0.547 \\
(0.38)\end{array}$ \\
\hline SOE & $\begin{array}{c}-0.581 * * * \\
(-2.81)\end{array}$ & $\begin{array}{c}-0.528 * * * \\
(-2.79)\end{array}$ & $\begin{array}{c}-0.709 * * * \\
(-3.52)\end{array}$ \\
\hline CEO Duality & $\begin{array}{l}-0.215 \\
(-1.61)\end{array}$ & $\begin{array}{l}-0.100 \\
(-0.66)\end{array}$ & $\begin{array}{l}-0.191 \\
(-1.45)\end{array}$ \\
\hline Industry FEs & & $\mathrm{Y}$ & \\
\hline Year FEs & & $\mathrm{Y}$ & \\
\hline Province FEs & & $\mathrm{Y}$ & \\
\hline Observations & 758 & 531 & 765 \\
\hline Pseudo R-squared & 0.128 & 0.126 & 0.126 \\
\hline
\end{tabular}




\section{Appendix E: Instrumental variable approach for M\&A tendency}

This table reports the results using the instrumental variable approach for M\&A tendency. M\&A is a dummy that equals one if the firm announces a merger and acquisition, and zero otherwise. Pledge_Percent equals the percentage of shares pledged by the controlling shareholders at the year-end. Pledge_Percent (Peer) is the instrumental variable. In column (1), the instrument, Pledge_Percent (Peer), is defined as the average percent of shares pledged by the controlling shareholders from the peer companies operating in the same industry and located in the same province. In column (2), peers with M\&A activities during the [-1, +1] year window are excluded when calculating the instrument. Pledge_Percent (Predicted) is the fitted value of Pledge_Percent. Column (1) and (2) report the second stage regressions. The definition of other controls are listed in Appendix A. The regressions include industry, year and province fixed effects. The t-statistics in parentheses are based on standard errors adjusted for firm-level clustering. $* * *, * *, *$ represent statistical significance at the $1 \%, 5 \%$ and $10 \%$ levels, respectively.

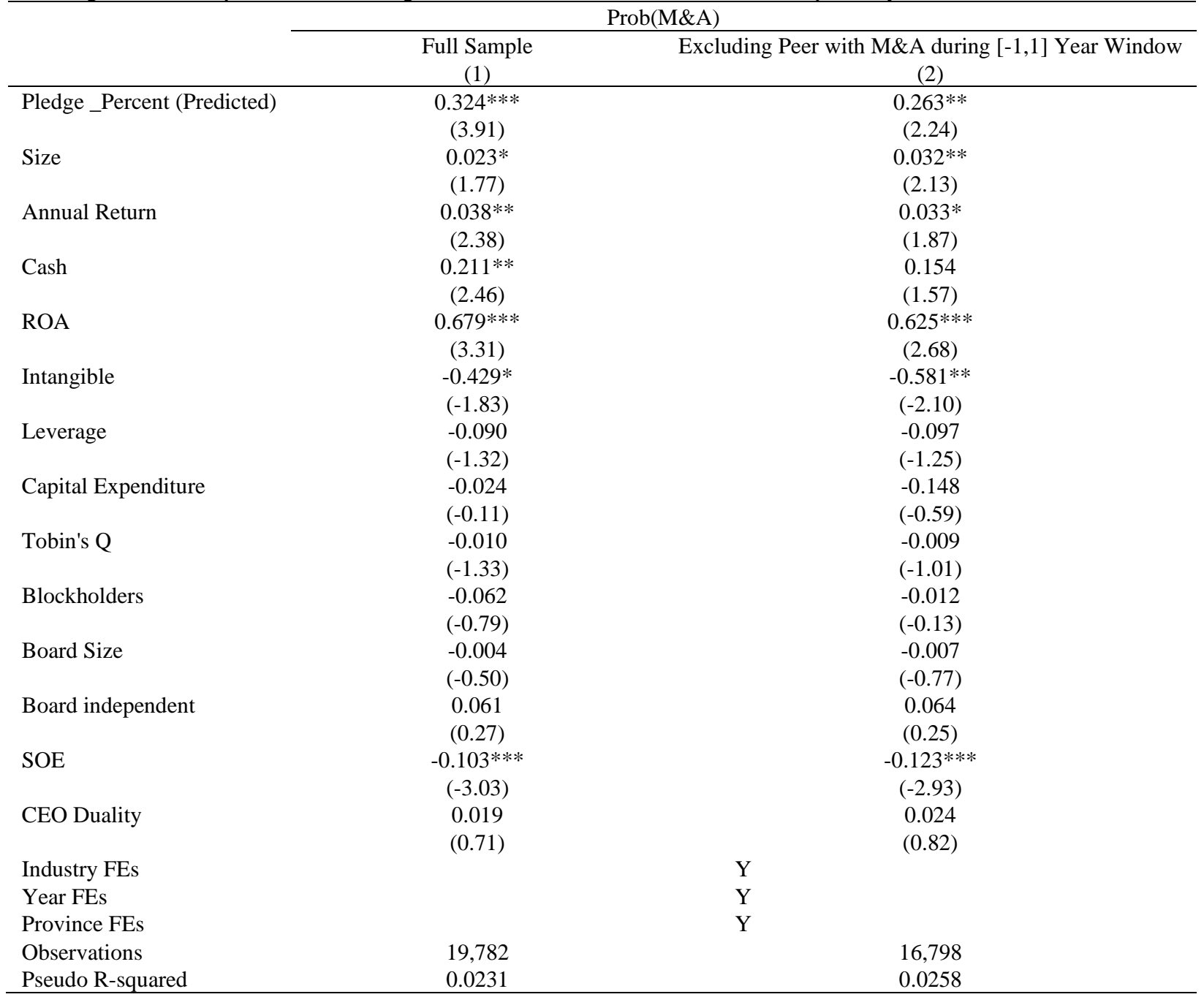

